\title{
(RE)VEILED RACISM IN BRAZIL: RECOGNITION AS A WAY OF CONFRONTING IT THROUGH ANTI-RACIST ACTIONS
}

\section{O RACISMO (RE)VELADO NO BRASIL: RECONHECIMENTO COMO MEIO DE ENFRENTAMENTO A PARTIR DE AÇÕES ANTIRRACISTAS}

\author{
Carla Bertoncini ${ }^{1}$ \\ Tayana Roberta Muniz Caldonazzo ${ }^{2}$
}

\begin{abstract}
The present study, related to the Law area, sub-area Constitutional Law, studies racism in Brazil, thinking about its reproduction over the years until the way it is revealed today. Alarming data in studies indicate racism in physical violence, homicides, disrespect to culture and religiosity, among other manifestations. The objective is to highlight the reproduction of racism over the years until the way it is revealed in contemporary times, in order to point out that the recognition of this situation tends to be a means of confronting it. Thus, the following problem is studied: how can racism be faced in Brazil? To answer the question, the hypothesis - which has been confirmed - is that the recognition of this structural reality tends to be a way to think and manage anti-racist actions, including specific public policies against this violence, not only attributing to the past the responsibility for current attitudes. The deductive method was used, in addition to bibliographic and electronic research in books, theses, dissertations, journals and reports.
\end{abstract}

Keywords: Structural racism; Recognition; Anti-racist actions; Violence; Racial inequality.

\section{RESUMO}

O presente trabalho, vinculado à área do Direito, subárea Direito Constitucional, estuda o racismo no Brasil, pensando-se na sua reprodução ao longo dos anos até a maneira como se revela na atualidade. Dados alarmantes em estudos indicam o racismo em violências físicas,

\footnotetext{
${ }^{1}$ Bacharel em Direito pela Instituição Toledo de Ensino - ITE (1992), Mestre em Direito pela Instituição Toledo de Ensino - ITE (2001) e Doutora em Direito pela Pontifícia Universidade Católica de São Paulo (subárea de concentração Direito Civil) - PUC (2011). Atualmente é professora adjunta do curso de Pós-graduação stricto sensu (Mestrado) e do curso de graduação da Faculdade de Direito do Centro de Ciências Sociais Aplicadas da Universidade Estadual do Norte do Paraná - UENP, Campus de Jacarezinho e professora de Direito Civil (Direito de Família e Sucessões) das Faculdades Integradas de Ourinhos (FIO). Universidade Estadual do Norte do Paraná; Centro Universitário das Faculdades Integradas de Ourinhos - Brasil. ORCID: https://orcid.org/0000-0002-41162431 Lattes: http://lattes.cnpq.br/8287398590266450 E-mail: carla.bertoncini@uenp.edu.br

${ }^{2}$ Graduou-se em Direito pela Universidade Estadual do Norte do Paraná (Uenp) - campus de Jacarezinho. Atualmente é Mestranda do Programa de Pós-Graduação em Ciência Jurídica da Universidade Estadual do Norte do Paraná (UENP) (Área de Concentração: Teorias da Justiça e Exclusão; Linha de pesquisa: Função Política do Direito). É bolsista pela Coordenação de Aperfeiçoamento de Pessoal de Nível Superior (CAPES). Participa do Grupo de Pesquisa Intervenção do Estado na Vida das Pessoas. Universidade Estadual do Norte do Paraná - Brasil. ORCID: http://orcid.org/0000-0001-8507-0689 Lattes: http://lattes.cnpq.br/9759779920993502 E-mail: tayanaroberta@yahoo.com.br
} 
homicídios, desrespeito à cultura e religiosidade, dentre outras manifestações. Diante disso, objetiva-se evidenciar a reprodução do racismo ao longo dos anos até a maneira como se revela na contemporaneidade, a fim de apontar que o reconhecimento dessa situação tende a ser um meio de enfrentamento. Assim, parte-se do seguinte problema: de que forma é possível enfrentar o racismo no Brasil? Para responder ao questionamento, a hipótese - que se confirmou - é de que o reconhecimento dessa realidade estrutural tende a ser um meio para que se pensem e sejam manejadas ações antirracistas, inclusive políticas públicas específicas contra essa violência, não se atribuindo somente ao passado a responsabilidade por posturas atuais. Utilizou-se o método dedutivo, somado a pesquisas bibliográficas e eletrônicas em livros, teses, dissertações, periódicos e reportagens.

Palavras-chave: Racismo estrutural; Reconhecimento; Ações antirracistas; Violência; Desigualdade racial.

\section{INTRODUCTION}

This research, related to the Area of Law, sub-area Legal Sociology, analyzed the reproduction and perpetuation of racism in Brazil, although this is a worldwide phenomenon. It is justified, because despite the provision for the right to non-discrimination in the Federal Constitution, infra-constitutional laws, among other provisions, data demonstrated how violence against black people is in the majority, such as the 2016 Map of Violence, which deals with firearm homicides in Brazil, Atlas of Violence 2019, among other sources.

There was the following problem: how can racism be faced in Brazil? To answer the question, the hypothesis was that the recognition of this structural reality tends to be a skillful instrument to think and manage anti-racist actions ${ }^{3}$, including public policies, not relegating only to the past the responsibility for current attitudes.

To achieve the proposal, the first section examined the influence of colonization and pseudo-scientific theories - which raised hierarchies between individuals - on the spread of racism. Later, the importance of memory was explored, as it is more complete than history (SCHWARCZ, 2019), in the study of this theme. The myth of racial democracy, its current reflections and the importance of the recognition of prejudice - and consequent discrimination present in the thinking, actions and policies of Brazil - were approached as a way of thinking about specific public policies to address the issue. Examples of strategies to improve this reality were pointed out, demonstrating the importance of new studies on the subject. Finally, there

\footnotetext{
${ }^{3}$ The term "antirracist" can be found in researches by authors such as Almeida (2018) and Ribeiro (2019).
} 
were demonstrations of structural racism, whether at the institutional, cultural or religious level, in order to illustrate this reality.

The deductive method was used, starting from the premise that there are still (re)veiled forms of racism in society, institutions and the State, despite legal provisions, such as the Federal Constitution and others - providing for the right to non-discrimination. In order to face this reality, it was proposed to recognize it so that anti-racist actions could be implemented, including effective and specific public policies, considering specially Ribeiro (2019), Almeida (2018) e Gonzalez (1988). Electronic and bibliographic research has been carried out by reading books, theses, dissertations, journals and reports. The literature review helped to find relevant authors on the subject, reaching the bibliographic review of structural racism and its consequences.

\section{THE BASES OF RACISM IN BRAZIL}

It is important to consider the place of speech in this study as an ethical-political guide (LIMA, 2018, p. 28). The authors speak from their social locations (RIBEIRO, 2017), characterized, among other points, by the fact that they are white, which generates privileges (RIBEIRO, 2019). In an analogical way to Lima (2018, p. 28), however, this does not prevent from thinking about instruments to face racism in Brazil. For Ribeiro (2017), everyone has a place of speech, which must not be confused with representativeness.

In spite of the fact that the legal system values equality - following the example of the Federal Constitution of $1988^{4}$, infra-constitutional laws, such as Law $n^{\circ} 7.716$, of 1989, among others -, it is common that several acts of violence fall upon individuals, in a targeted manner,

\footnotetext{
${ }^{4}$ Jones (1973), cited by Santana and Pereira (2018, p. 1554, authors' emphasis, our translation) argues that there are three different forms of expression of racism: "individually, when an individual considers that black people, as a group, are inferior, to whites [...]; institutionally, racism can be manifested or hidden, visible when complex interrelational relations between the institutions of society make the long-term effects of an institutional practice negative and can manifest itself in the economy, in education and in bureaucratic systems of justice; it can also manifest itself in the cultural form, defining itself as an individual and institutional expression of the superiority of the cultural heritage of one race in relation to another". (Original: "individualmente, quando um indivíduo considera que as pessoas negras, como um grupo, são inferiores, aos brancos [...]; institucionalmente, o racismo pode ser manifestado ou oculto, visíveis quando complexas relações inter-relacionais entre as instituições da sociedade fazem com que os efeitos em longo prazo de uma prática institucional sejam negativos, podendo se manifestar na economia, na educação e nos sistemas burocráticos de justiça; pode se manifestar, ainda, na forma cultural, definindo-se como expressão individual e institucional da superioridade da herança cultural de uma raça em relação à outra"). The authors criticize that the Federal Constitution, by providing for the crime of racism, ended up neglecting the modalities of institutional and cultural racism, receiving a focus primarily on individual manifestations (SANTANA; PEREIRA, 2018).
} 
due to aspects that mark their identities ${ }^{5}$, such as race, color, ethnicity, origin, among other factors.

In fact, the Federal Constitution prohibits discrimination in article 3, item IV, at the same time that article 5 brings a series of guarantees to Brazilians and foreigners regarding life, freedom, equality, among others, as well as providing instruments aimed at guaranteeing these rights (BRASIL, 2009). Law $\mathrm{n}^{\circ} 7.716$, of 1989, criminalizes acts resulting from prejudice or discrimination based on race, color, ethnicity, religion or national origin, according to Article 1, and "defines crimes resulting from prejudice of race or color" (BRASIL, 1989, our translation $)^{6}$.

However, despite these provisions aimed at guaranteeing rights, there are recurrent violations in brazilian reality, so that the practice of xenophobia, racial and gender discrimination carry a balance of violence, deaths and struggle. So, the debate on racism is part of the present work. It seeks to contextualize how the process of colonization and pseudoscientific theories ${ }^{7}$, which defend arguments supposedly capable of justifying domination, have contributed to the diffusion and perpetuation of racism.

All individuals should be equally respected, and it is not legitimate to consider someone superior to others (COMPARATO, 2010) - just as should be proceed in relation to social groups, cultural manifestations, etc. Nevertheless, there are those who believe - and act - in the opposite way, as happens in the crimes of racism. For Almeida (2018), based in Banton (2012), the use of the expression "race" to differentiate individuals is something that refers to modernity, specifically the sixteenth century.

According to Barros and Martins (2019, p. 34, author's translation), the notion of race is important for the understanding of racism, and brings the "perception or belief in a natural hierarchy among [...] [people] based on their physical characteristics that, in turn, imply the moral and intellectual characteristics" ${ }^{8}$. Race is market by an ideology, and masks the relationship of domination and power (MUNANGA, 2003). In addition, racism is:

[...] would theoretically be an essentialist ideology that postulates the division of humanity into large groups called contracted races that have common hereditary physical characteristics, the latter being supports of psychological, moral,

\footnotetext{
${ }^{5}$ According to Moreira (2017), individuals may suffer different discriminatory processes precisely because of the multiplicity of identities.

6 "Define os crimes resultantes de preconceito de raça ou de cor" (BRASIL, 1989).

${ }^{7}$ Term quoted by Angela Davis (2016, p. 205), when referring to Bonnie's lessons, and Munanga (2003).

8 “percepção ou crença em uma hierarquia natural entre os homens baseada em suas características físicas que, por sua vez, implicam nas características morais e intelectuais” (MARTINS; BARROS, 2019, p. 34).
} 
intellectual and aesthetic characteristics and are situated on a scale of unequal values. From this point of view, racism is a belief in the existence of races naturally hierarchized by the intrinsic relationship between the physical and the moral, the physical and the intellectual, the physical and the cultural. The racist creates race in the sociological sense, that is, race in the imaginary of the racist is not exclusively a group defined by physical traits. The race in his head is a social group with cultural, linguistic, religious, etc. that he considers naturally inferior to the group to which he belongs. Otherwise, racism is this tendency that consists in considering that the intellectual and moral characteristics of a given group are consequences of its physical or biological characteristics (MUNANGA, 2003, unpaged, author's translation) ${ }^{9}$.

Silvio Almeida points that there is differentiation between prejudice, race and discrimination ${ }^{10}$. In addition, highlights the correlation between colonization and racism, as well science make-up lenses ${ }^{11}$ that justified the hierarchies, through scientific racism. According to the author, the Enlightenment allowed comparisons and classifications between groups of human beings considering physical or cultural issues that characterized them. A distinction was made between those who were civilized and savage, and those who were civilized and primitive in the later century. Still, the movement served as a basis for liberal revolutions, which fought against absolutism and nobility. Society was gradually transformed

\footnotetext{
9 “[...] seria teoricamente uma ideologia essencialista que postula a divisão da humanidade em grandes grupos chamados raças contratadas que têm características físicas hereditárias comuns, sendo estas últimas suportes de características psicológicas, morais, intelectuais e estéticas e se situam numa escala de valores desiguais. Visto deste ponto de vista, o racismo é uma crença na existência das raças naturalmente hierarquizadas pela relação intrínseca entre o físico e o moral, o físico e o intelecto, o físico e o cultural. O racista cria a raça no sentido sociológico, ou seja, a raça no imaginário do racista não é exclusivamente um grupo definido pelos traços físicos. A raça na cabeça dele é um grupo social com traços culturais, linguísticos, religiosos, etc. que ele considera naturalmente inferiores ao grupo a qual ele pertence. De outro modo, o racismo é essa tendência que consiste em considerar que as características intelectuais e morais de um dado grupo, são consequências de suas características físicas ou biológicas" (MUNANGA, 2003, p. 7-8).

10 "Racism is a systematic form of discrimination based on race and manifested through conscious or unconscious practices that culminate in disadvantages or privileges for individuals, depending on the racial group to which they belong. Racial prejudice is the judgment based on stereotypes about individuals belonging to a particular racialized group, which may or may not result in discriminatory practices. To consider blacks violent and unreliable, greedy Jews [...] are examples of prejudice. Racial discrimination, in turn, is the attribution of differential treatment to members of racially identified groups. Therefore, discrimination has as a fundamental requirement the power, that is, the effective possibility of the use of force, without which it is not possible to attribute advantages or disadvantages on account of race. Thus, discrimination can be direct or indirect" (ALMEIDA, 2018, p. 25, author's emphasis, our translation). Original: "Racismo é uma forma sistemática de discriminação que tem a raça como fundamento, e que se manifesta por meio de práticas conscientes ou inconscientes que culminam em desvantagens ou privilégios para indivíduos, a depender do grupo racial ao qual pertençam. [...] O preconceito racial é o juízo baseado em estereótipos acerca de indivíduos que pertençam a um determinado grupo racializado, e que pode ou não resultar em práticas discriminatórias. Considerar negros violentos e inconfiáveis, judeus avarentos [...] são exemplos de preconceitos. A discriminação racial, por sua vez, é a atribuição de tratamento diferenciado a membros de grupos racialmente identificados. Portanto, a discriminação tem como requisito fundamental o poder, ou seja, a possibilidade efetiva do uso da força, sem o qual não é possível atribuir vantagens ou desvantagens por conta da raça. Assim, a discriminação pode ser direta ou indireta" (ALMEIDA, 2018, p. 25, grifos do autor).
}

${ }^{11}$ As interpreted by the authors. 
from feudalism to capitalism (ALMEIDA, 2018), "in which the philosophical composition of universal man, universal rights and universal reason proved fundamental to the victory of civilization" (p. 21, our translation) ${ }^{12}$.

However, this "civilization", in the next century, would be taken to places where it supposedly did not exist, a movement that led to various damages, such as death, exploitation, destruction, due to colonialism (ALMEIDA, 2018). After explaining about the Haitian Revolution - and how it was not well regarded by the French, despite seeking similar goals to the French Revolution, such as equality and freedom, and positioning themselves against a tyrannical power - he concludes that the Enlightened ideals did not transform individuals into equals $^{13}$ (ALMEIDA, 2018). Furthermore, the author explains that "the classification of human beings would serve, more than for philosophical knowledge, as one of the technologies of European colonialism for the destruction of peoples in the Americas, Africa, Asia and Oceania" (ALMEIDA, 2018, p. 21, author's translation) ${ }^{14}$.

Later, the influence of positivism in the nineteenth century characterized reflections on differences between human beings as something scientific. Physics and biology were used to explain human heterogeneity (ALMEIDA, 2018), giving rise to the belief "that biological characteristics - biological determinism - or climatic and/or environmental conditions geographical determinism - would be able to explain the moral, psychological and intellectual differences between the different races" (p. 23, our translation) ${ }^{15}$. Non-white skins, as well as a tropical climate, were associated with negative behaviors and lack of intelligence. This argument is called "scientific racism", and was widely disseminated and well regarded in the nineteenth century, including in the political and academic spheres ${ }^{16}$ (ALMEIDA, 2018).

Munanga (2003, p. 9, our translation) highlights the fact that "racism is born when biological characters are intervened as a justification of such or such behavior" ${ }^{17}$. From the

\footnotetext{
12 "em que a composição filosófica do homem universal, dos direitos universais e da razão universal mostrou-se fundamental para a vitória da civilização" (ALMEIDA, 2018, p. 21).

${ }^{13}$ At this point, Almeida (2018) was based in Losurdo (2006).

${ }^{14}$ Original: "a classificação dos seres humanos serviria, mais do que para o conhecimento filosófico, como uma das tecnologias do colonialismo europeu para a destruição de povos nas Américas, da África, da Ásia e da Oceania" (ALMEIDA, 2018, p. 21).

15 “de que características biológicas - determinismo biológico - ou condições climáticas e/ou ambientais determinismo geográfico - seriam capazes de explicar as diferenças morais, psicológicas e intelectuais entre as diferentes raças" (ALMEIDA, 2018, p. 23).

${ }^{16}$ As Hale (2009), quoted by Almeida (2018).

17 "o racismo nasce quando faz-se intervir caracteres biológicos como justificativa de tal ou tal comportamento" (MUNANGA, 2003, p. 9).
} 
moment the correlation between ethnicity and nationalism began to be strengthened, biological explanations for the difference had emphasis (HUNT, 2009).

After the French Revolution, it became increasingly difficult to reaffirm differences simply on the basis of tradition, customs or history. Differences had to have a more solid foundation if men wanted to maintain their superiority over women, whites over blacks, or Christians over Jews. In short, if rights were to be less than universal, equal and natural, it was necessary to explain why. As a result, the sixteenth century witnessed an explosion of biological explanations of difference. Ironically, therefore, the very notion of human rights inadvertently opened the door to more virulent forms of sexism, racism and anti-Semitism. New forms of racism, anti-Semitism and sexism offered biological explanations for the natural character of human difference (HUNT, 2009, p. 187-188, author's translation $)^{18}$.

Thus, in the 19th century, opponents of rights for Jews and blacks relied on what was presented as science to justify their arguments. Two thoughts intertwined in that century (HUNT, 2009). The first was that "history had seen a successive development of peoples towards civilization and that whites were the most advanced in the group; and second, the idea that permanently inherited characteristics divided people according to race" (HUNT, 2009, p. 191, our translation $)^{19}$. In author's view, "racism, as a systematic doctrine, depended on the conjugation of the two" (HUNT, 2009, p. 191, author's translation) ${ }^{20}$, so that "the thinkers of the xvm century (sic) assumed that all peoples would eventually reach civilization, while the racial theorists of the xix century (sic) believed that only certain races would do so, because of their inherent biological qualities" (HUNT, 2009, p. 191, our translation) ${ }^{21}$.

In this context, it is observed the appearance of social Darwinism, standing out in the approach of differences among human beings (BARROS; MARTINS, 2019), so that "concepts such as the survival of the fittest and heredity, applied to humanity, start to circulate in the

\footnotetext{
18 "Depois da Revolução Francesa, tornou-se cada vez mais difícil reafirmar as diferenças simplesmente com base na tradição, nos costumes ou na história. As diferenças tinham de ter um fundamento mais sólido se os homens quisessem manter a sua superioridade em relação às mulheres, os brancos em relação aos negros ou os cristãos em relação aos judeus. Em suma, se os direitos deviam ser menos que universais, iguais e naturais, era preciso explicar por quê. Em consequência, o século xix presenciou uma explosão de explicações biológicas da diferença. Ironicamente, portanto, a própria noção de direitos humanos abriu inadvertidamente a porta para formas mais virulentas de sexismo, racismo e antissemitismo. [...] As novas formas de racismo, antissemitismo e sexismo ofereciam explicações biológicas para o caráter natural da diferença humana" (HUNT, 2009, p. 187-188).

19 “a história tinha visto um desenvolvimento sucessivo dos povos rumo à civilização e de que os brancos eram os mais avançados do grupo; e segundo, a ideia de que as características permanentemente herdadas dividiam as pessoas de acordo com a raça." (HUNT, 2009, p. 191).

20 “o racismo, como uma doutrina sistemática, dependia da conjugação dos dois" (HUNT, 2009, p. 191).

21 “os pensadores do século xvm (sic) pressupunham que todos os povos acabariam por alcançar a civilização, enquanto os teóricos raciais do século xix (sic) acreditavam que somente certas raças o fariam, por causa de suas inerentes qualidades biológicas" (HUNT, 2009, p. 191).
} 
scientific media" (p. 35, author's translation) ${ }^{22}$. "Base of a scientific racism [...], eventually translated into a kind of advanced practice of social Darwinism - eugenics - that intended to intervene in the reproduction of populations" (BARROS; MARTINS, 2019, p. 36, author's translation $)^{23}$.

About this subject, Schwarcz (2019) explains that determinist theories, also known as racial Darwinists, arose after the Golden Law did not provide ways of integrating individuals into brazilian society. These theories classified human beings into different races, each with its own intellectual, physical, and moral characteristics. In this model, whites and westerners remain at the apex of the social pyramid, while others are regarded as inferior, and have less potential. The "mestiços" were considered "degenerates", since their origin comes from the "mixture" of different races. These reasonings had as a central objective to justify the "natural" permanence of white men over other individuals. It replaced the inequality coming from the slave regime with an inequality based on biology.

Considering this biological notion of difference, built in order to hierarchize individuals, Munanga (2003), when exposing several factors used as criteria for classification among human beings, states to be indisputable "that race is not a biological reality, but only a concept moreover scientifically inoperative to explain human diversity and to divide it into races. That is, biologically and scientifically, the races do not exist" (MUNANGA, 2003, p. 5, our translation $)^{24}$. For him, "the classification of humanity in hierarchical races led to a pseudoscientific theory, the raciologia" (MUNANGA, 2003, p. 05, our translation) ${ }^{25}$, which would have a doctrinal content and helped legitimize systems of racial domination. It was diffused among the dominant western population, and also served as a basis for nationalisms that emerged, like Nazism, to allow exterminations of individuals (MUNANGA, 2003).

Although the origins of racism preferentially indicate the economic reasons for plundering and conquering territories, and/or policies of conquest and domination of peoples, today the racial question is autonomized, that is, the racial discrimination suffered by black individuals and their descendants, goes beyond

\footnotetext{
22 "conceitos como a sobrevivência dos mais aptos e hereditariedade, aplicados à humanidade, passam a circular nos meios científicos” (BARROS; MARTINS, 2019, p. 35).

23 "Base de um racismo científico [...], acabou por se traduzir em uma espécie de prática avançada do darwinismo social - a eugenia - que pretendia intervir na reprodução das populações, através do que consideravam nascimentos desejáveis" (BARROS; MARTINS, 2019, p. 36).

24 "que a raça não é uma realidade biológica, mas sim apenas um conceito aliás cientificamente inoperante para explicar a diversidade humana e para dividi-la em raças. Ou seja, biológica e cientificamente, as raças não existem" (MUNANGA, 2003, p. 5).

25 "a classificação da humanidade em raças hierarquizadas desembocou numa teoria pseudo-científica, a raciologia” (MUNANGA, 2003, p. 05).
} 
the social, political or economic question to walk alongside them, with their own specific characteristics and justifications (BERTÚLIO, 1989, p. XIII, our translation $)^{26}$.

Despite current racial discrimination as a reflection, among other factors, of these theories and processes of colonization, some people refuse to believe that racism is a reality. According to Moreira ${ }^{27}$ (2017), black people are constant victims of police violence, have less school time, receive lower salaries, suffer racial injury, and this situation arises "from the permanence of cultural stereotypes ${ }^{28}$ that legitimize exclusionary practices in various spheres of social life, a process masked by the influence of the notion of racial neutrality in the cultural and political sphere" (p. 251, our translation) ${ }^{29}$. It indicates violation of the right to nondiscrimination provided for in the Federal Constitution and infra-constitutional legislation.

Thus, there are several explanations that have tried to justify differences among human beings, aiming only to maintain the status quo of privileges of part of the population over others. There were - and still are - interests in the perpetuation of racism and discrimination. To face the situation, however, it is important to recognize this structural reality ${ }^{30}$, an issue that will be addressed in the next items.

\footnotetext{
26 "Ainda que as origens do racismo indiquem preferencialmente as razões econômicas de pilhagem e conquista de territórios, e/ou políticas de conquista e dominação de povos, hoje a questão racial está autonomizada, vale dizer, a discriminação racial que sofre o indivíduo negro e seus descendentes, extrapola a questão social, política ou econômica para caminhar ao lado delas, com características e justificativas próprias e específicas" (BERTÚLIO, 1989, p. XIII).

${ }^{27}$ In concluding his considerations, the author refers to Telles (2005).

28 "Stereotyped are generalizations that people make about behaviors or characteristics of others, mobilized doubly by the conscious relationship of an individual knowledge and a collective knowledge. Stereotype can also be seen as assumptions about certain people [...] Under that sense, the concept of stereotype can be confused with the concept of prejudice [...]" (ARAÚJO, 2014, p. 2, author's translation). In original: "Entende-se por estereótipo generalizações que as pessoas fazem sobre comportamentos ou características de outros, mobilizadas duplamente pela relação consciente de um saber individual e de um saber coletivo. O estereótipo pode ser visto também como pressupostos sobre determinadas pessoas [...] Sob essa acepção, o conceito de estereótipo pode ser confundido com o conceito de preconceito [...]" (ARAÚJO, 2014, p. 2).

29 “da permanência de estereótipos culturais que legitimam práticas excludentes em diversas esferas da vida social, processo mascarado pela influencia da noção de neutralidade racial no âmbito cultural e político" (MOREIRA, 2017, p. 251).

${ }^{30}$ For Ribeiro (2019), the discussion on racism in Brazil requires a structural debate. It is important to talk about the link between slavery, racism and its consequences. Thus, it is importante to analyze how this system brought economic advantages to whites, while black people received a treatment similar to a commodity, besides not having basic rights and suffering inequalities related to the distribution of wealth.
} 


\title{
3. HISTORY AND MEMORY OF RACISM: RECOGNISING IS A WAY OF FACING
}

\author{
The recognition of racism goes beyond the attribution of guilt to the slavery period, and
} the responsibility for current violence cannot be relegated to the past alone, as can be seen from the lessons from Schwarcz (2019), Bento (2002), Santos e Silva (2017), Hasenbalg (2005) ${ }^{31}$. However, it is important to bring informations from this time lapse in a broad study on the subject, in order to verify the history of racial inequality.

Bertúlio, (1989) warns that slavery ${ }^{32}$ existed in Brazil for approximately four centuries. The history of this country is particular when related to its Latin American neighbors

\footnotetext{
${ }^{31}$ Quoted by Santos e Silva (2017).

32 "On the relationship between slavery and racism, there are basically two explanations. The first part of the affirmation that racism arises from the marks left by slavery and colonialism. According to this thinking, contemporary societies, even after the official end of the slave regimes, would remain stuck in mental and institutional slave patterns, that is, racist, authoritarian and violent. In this way, racism would be a kind of remnant of slavery, an essential contamination that, especially in peripheral countries, would prevent the modernization of economies and the emergence of democratic regimes. [...] Another current, despite not denying the terrible impacts of slavery on Brazilian economic and social formation, will say that contemporary forms of racism are products of advanced capitalism and modern rationality and not remnants of a past that does not pass away. Racism is not the rest of slavery, even because there is no opposition between modernity/capitalism and slavery. Slavery and racism are constitutive elements of both modernity and capitalism, so that there is no talk of one without the other. Racism, according to this position, is a manifestation of the structures of capitalism, which were forged by slavery. This means that racial inequality is a constitutive element of mercantile relations and class relations, such that the modernization of the economy and even its development can also represent moments of adaptation of racial parameters to new stages of capitalist accumulation. In short: in order to renew itself, capitalism often needs to renew racism, such as replacing official racism and legalized segregation with indifference to racial equality under the cloak of democracy. Economic growth can be considered the increase in production and profit, which does not necessarily imply an increase in wages. In this context, racism can be an excellent technology of social control because it 'naturalizes' the payment of lower wages to workers belonging to minority groups. (ALMEIDA, 2018, p. 144, author's translation). Original: "Sobre a relação entre escravidão e racismo, há basicamente, duas explicações. A primeira parte da afirmação de que o racismo decorre das marcas deixadas pela escravidão e pelo colonialismo. Conforme este raciocínio, as sociedades contemporâneas, mesmo após o fim oficial dos regimes escravistas, permaneceriam presas a padrões mentais e institucionais escravocratas, ou seja, racistas, autoritários e violentos. Dessa forma, o racismo seria uma espécie de resquício da escravidão, uma contaminação essencial que, especialmente nos países periféricos, impediria a modernização das economias e o aparecimento de regimes democráticos. [...] Outra corrente, apesar de não negar os impactos terríveis da escravidão na formação econômica e social brasileira, dirá que as formas contemporâneas do racismo são produtos do capitalismo avançado e da racionalidade moderna e não resquícios de um passado que não passa. O racismo não é um resto da escravidão, até mesmo porque não há oposição entre modernidade/capitalismo e escravidão. A escravidão e o racismo são elementos constitutivos tanto da modernidade quanto do capitalismo, de tal modo que não há falar de um sem o outro. O racismo, de acordo com essa posição, é uma manifestação das estruturas do capitalismo, que foram forjadas pela escravidão. Isso significa dizer que a desigualdade racial é um elemento constitutivo das relações mercantis e das relações de classe, de tal sorte que a modernização da economia e até seu desenvolvimento também podem representar momentos de adaptação dos parâmetros raciais a novas etapas da acumulação capitalista. Em suma: para se renovar, o capitalismo precisa, muitas vezes, renovar o racismo, como, por exemplo, substituir o racismo oficial e a segregação legalizada pela indiferença em face da igualdade racial sob o manto da democracia. $\mathrm{O}$ crescimento econômico pode ser considerado o aumento da produção e do lucro, o que não necessariamente implica em aumento de salário. Nesse contexto, o racismo pode ser uma excelente tecnologia de controle social porque, "naturaliza' o pagamento de salários mais baixos para trabalhadores e trabalhadoras pertencentes a grupos minoritários.” (ALMEIDA, 2018, p. 144).
} 
(SCHWARCZ, 2019), and "almost half of Africans enslaved and forced to leave their lands of origin at the base of force and violence came here" (p. 11, our translation) $)^{33}$. It was also the last country to abolish this form of forced labour in the Americas (SCHWARCZ, 2019). In 1822, when Brazil's independence was proclaimed, the scenario was one of "an illiterate population, a slave society, a monoculturist and landowner economy, an absolutist state" (CARVALHO, 2008 , p. 18, author's translation) ${ }^{34}$. It is estimated that until the year of independence, approximately three million enslaved people were brought to the colony (CARVALHO, 2008).

The objectification and dehumanization existing in the slave period are notable, and violations of various kinds of human dignity occur. Black people were seen as property (DAVIS, 2016), and more specifically as "semovent goods, that is, things that move with their own traction, similar to animals" (ALMEIDA, 2018, p. 103, author's translation) ${ }^{35}$. Batista, citing Zaffaroni and Batista (2018, p. 96, author's translation), points that "the kidnappings of slaves ${ }^{36}$ were considered theft, and the slave was only subject before the penal system" ${ }^{37}$. There was even the "rent" of enslaved people, generating income (CARVALHO, 2008).

The traffic of enslaved people was forbidden in 1850, and through Law $\mathrm{n}^{\circ} 3.353$ of 1888, slavery was abolished in Brazil. The abolitionist movement understood that the Golden Law would cease the existing problems. It defended the liberation of enslaved and the end of an archaic and broken regime that delayed the progress of Brazil, if compared to other nations, and the insertion of black people in society, as citizens, was not a focus ${ }^{38}$ (BERTÚLIO, 1989).

Through this movement, it was noticed that the majority of the Brazilian inhabitants were composed of black people (BERTÚLIO, 1989). They were seen as a national problem, and two perspectives were installed in the country (BARROS; MARTINS, 2019): one concluded for the "impracticability of the nation, for the great presence of blacks and racial mixture, which would have compromised a large part of the population, and another that elected our miscegenation as a redeemer of the black evil that [...] would dilute in the encounter with

\footnotetext{
33 "para cá veio quase a metade dos africanos e africanas escravizados e obrigados a deixar suas terras de origem na base da força e da violência" (SCHWARCZ, 2019, p. 11).

34 "população analfabeta, uma sociedade escravocrata, uma economia monocultora e latifundiária, um Estado absolutista" (CARVALHO, 2008, p. 18).

35 "bens semoventes, ou seja, coisas que se movem com tração própria, semelhante a animais" (ALMEIDA, 2018, p. 103).

${ }^{36}$ Ribeiro (2019) understands that the black population was enslaved (in portuguese, "escravizada"), instead of "slave" ("escrava", in original), because this term refers to a supposed natural condition, omitting the fact that these people were forced into that situation.

37 "os sequestros de escravos eram considerados furtos, e o escravo só era sujeito diante do sistema penal". (ZAFFARONI; BATISTA; CITED BY BATISTA, 2018, p. 26).

${ }^{38}$ Also in this direction, Carvalho (2008).
} 
the white race [...]" (p. 37, author's translation) ${ }^{39}$. Thus, the "white elite [...] quickly moved towards the 'resolution' of yet another problem. The solution found was 'only one staff for the death of two rabbits': European immigration" (BERTÚLIO, 1989, p. XXII-XXIII, author's translation $)^{40}$.

Socio-economic crises crossed the population of Europe, and offers of land and jobs were attractive to immigrants. Thus, the Brazilian government encouraged the immigration of whites in several ways. (BERTÚLIO, 1989). Barros and Martins (2019, p. 39, our translation) point that for some intellectuals, the arrival of European immigrants "brought a second benefit, other than the arrival of superior individuals to assume the process of development of the country $[\ldots]$, and this second benefit would be to mix the native population and thus whiten it $[\ldots]^{\prime 41}$. In this sense, "scientific racism in Brazil [...] pointed out that the mestiço was admitted as a transitory element that would lead to the constitution of a nation of whites" (SANTOS; SILVA, 2017, p. 450, author's translation) $)^{42}$.

So, there has been an attempt of whitening ${ }^{43}$ the population through the immigration of European individuals. Bento (2002, p. 7, author's translation), citing Azevedo's studies, alludes to the fact that "the ideal of whitening is born of fear, building on the form found by the Brazilian white elite at the end of the last century to solve the problem of a threatening country, mostly non-white"44, and this situation would have led to European immigration policy (BENTO, 2002).

\footnotetext{
39 “inviabilidade da nação, pela grande presença de negros e mistura racial, que teria comprometido grande parte da população, e outra que elegia nossa miscigenação como redentora do mal negro que [...] diluiria no encontro com a raça branca [...]" (BARROS; MARTINS, 2019, p. 37).

40 “elite [...] branca, rapidamente se movimentou em prol da 'resolução' de mais este problema. A saída encontrada era 'só um cajado para a morte de dois coelhos': a imigração europeia" (BERTÚLIO, 1989, p. XXII-XXIII).

41 "trazia um segundo benefício, que não a vinda de indivíduos superiores para assumir o processo de desenvolvimento do país [...], e esse segundo benefício seria misturar-se a população nativa e, assim, embranquecêla [...]” (BARROS; MARTINS, 2019, p. 39).

42 "o racismo científico no Brasil [...] apontava que o mestiço era admitido como elemento transitório que levaria a constituição de uma nação de brancos" (SANTOS; SILVA, 2017, p. 450).

43 "Whitening means adopting a whole universe of behaviors and values considered white, repelling, in turn, everything that was associated with black - capoeira, samba, religion - nothing fit the new Republic. Drunkenness, violence and lewd behavior were also associated with black people, which were considered and reproduced in the newspapers at the time as a result of their racial characteristics" (SCHWARCZ, 2010; APUD BARROS; MARTINS, 2019, p. 40, author's translation). Original: "Branquear significa adotar todo um universo de comportamentos e valores tidos como branco, repelindo, por seu turno, tudo o que fosse associado ao negro capoeira, samba, religião - nada se encaixava na nova República. Também a bebedeira, a violência, o comportamento lascivo eram associados aos negros, tidos e reproduzidos nos jornais da época como resultantes das suas características raciais" (SCHWARCZ, 2010; APUD BARROS; MARTINS, 2019, p. 40).

44 "o ideal de branqueamento nasce do medo, construindo-se na forma encontrada pela elite branca brasileiro no final do século passado para resolver o problema de um país ameaçador, majoritariamente não-branco" (BENTO, 2002, p. 7).
} 
Also due to immigration, the black population ended up neglected in free work, living and surviving on the peripheries of society. Black people were left with the necessary jobs, but not included in the formal network, and were gradually labeled as contrary to labor, beggars and criminals (BERTÚLIO, 1989).

There was even the return of some individuals to the context of the farms, earning low wage $^{45}$. Thus, even after decades of abolition, some lived on farms, without significant improvement in their living conditions; others went to the cities, such as Rio de Janeiro, without, however, having a fixed job. In places where there was economic development due to coffee production - as occurred in São Paulo - jobs belonged to Italian immigrants. As a rule, there were only gross and low paid Jobs for them ${ }^{46}$ (CARVALHO, 2008).

Thus, European immigration aimed, among other objectives, "to replace black labor and, to a certain extent, that of the poor white native, since it was understood that they were corrupted by the process of racial composition of the population" (BARROS; MARTINS, 2019, p. 38, author's translation) $)^{47}$.

Thus, a physical, behavioral, and cultural notion was stipulated as a standard, so that individuals who did not fit in would be excluded, to the extent that they were considered different. From Bento's analysis of whitening (2002), it's possible to understand that this is a process in which cultures other than those considered as patterns are inferior, thus opening up a negative view of differences:

In the description of this process [of whitening], white appears little, except as a universal model of humanity, the target of envy and the desire of other non-white racial groups and, therefore, regarded as not so human. In fact, when one studies whitening, finds that it was a process invented and maintained by the Brazilian white elite, although it was pointed out by this same elite as a problem of the Brazilian black. Considering (or perhaps inventing) their group as a reference standard for a whole species, the elite has made a crucial symbolic appropriation that has been strengthening the self-esteem and self-concept of the white group to the detriment of the others, and this appropriation ends up legitimizing their economic, political and social supremacy. The other side of this coin is the investment in the construction of an extremely negative imaginary about black people, which undermines their racial identity, damages their self-esteem, blames

\footnotetext{
${ }^{45}$ For Carvalho (2008), the abolition of slavery has not generated effective equality.

${ }^{46}$ The author clarifies that these conditions generate reflexes in contemporaneity. Thus, the black population is the group that has had the least chance to receive education in society; had the worst jobs, with low wages, among other points (CARVALHO, 2008).

47 "substituir a mão de obra negra e, até certa medida, a do branco pobre nativo, uma vez que se entendia que estava corrompido pelo processo de composição racial da população” (BARROS; MARTINS, 2019, p. 38).
} 
them for the discrimination they suffer and, finally, justifies racial inequalities (BENTO, 2002, p. 1-2, author's translation) $)^{48}$.

The author highlights the importance of white's role in the continuity of discrimination. In her vision, there is "a kind of pact, a tacit agreement among whites not to recognize themselves as an absolutely essential part of the permanence of racial inequalities in Brazil" (BENTO, 2002, p. 2, author's translation) $)^{49}$. Whites even "recognize racial inequalities, but do not associate these racial inequalities to discrimination and this is one of the first symptoms of whiteness" (BENTO, 2002 p. 3, our translation) ${ }^{50}$. "A person is not born white or black, but becomes from the moment the body and mind are connected to a whole network of collectively shared meanings, whose existence precedes the formation of the consciousness and the affections" $^{\text {51 }}$ (ALMEIDA, 2018, p. 53, author's translation).

Brazil's independence in $1822^{52}$ contributed to the criation of a goal relate to structuring a nation, which needed its own history (SCHWARCZ, 2019). Already in the 20th century, in the 1930s, there was a new interpretation of the race, marked by Gilberto Freyre (2002) (BARROS; MARTINS, 2019). The notion of scientific racism was replaced by the ideology of racial democracy (ALMEIDA, 2018). It is affirmed that "with Freyre (2002), the brazilian black gains a space of his own, is builder, together with the white and the indigenous, of the nation and its cultural heritage" (BARROS; MARTINS, 2019, p. 41, author's translation) ${ }^{53}$. His work Casa-grande \& Senzala "describes as successful the process of national formation supported not on a homogeneous racial basis, but organic and unitary, and can be read as a fundamental

\footnotetext{
48 "Na descrição desse processo [de branqueamento] o branco pouco aparece, exceto como modelo universal de humanidade, alvo da inveja e do desejo dos outros grupos raciais não-brancos e, portanto, encarados como não tão humanos. Na verdade, quando se estuda o branqueamento constata-se que foi um processo inventado e mantido pela elite branca brasileira, embora apontado por essa mesma elite como um problema do negro brasileiro. Considerando (ou quiçá inventando) seu grupo como padrão de referência de toda uma espécie, a elite fez uma apropriação simbólica crucial que vem fortalecendo a auto-estima e o autoconceito do grupo branco em detrimento dos demais, e essa apropriação acaba legitimando sua supremacia econômica, política e social. O outro lado dessa moeda é o investimento na construção de um imaginário extremamente negativo sobre o negro, que solapa sua identidade racial, danifica sua auto-estima, culpa-o pela discriminação que sofre e, por fim, justifica as desigualdades raciais" (BENTO, 2002, p. 1-2).

49 "uma espécie de pacto, um acordo tácito entre os brancos de não se reconhecerem como uma parte absolutamente essencial na permanência das desigualdades raciais no Brasil” (BENTO, 2002, p. 2).

50 "reconhecem as desigualdades raciais, só que não associam essas desigualdades raciais à discriminação e isto é um dos primeiros sintomas da branquitude" (BENTO, 2002, p. 3).

51 "uma pessoa não nasce branca ou negra, mas torna-se a partir do momento em que seu corpo e sua mente são conectados a toda uma rede de sentidos compartilhados coletivamente, cuja existência antecede à formação de sua consciência e de seus afetos" (ALMEIDA, 2018, p. 53).

${ }^{52}$ Carvalho (2008) points out that independence did not generate the end of slavery.

53 “com Freyre (2002), o negro brasileiro ganha um espaço seu, é construtor, junto com o branco e o índio, da nação e de seu patrimônio cultural” (BARROS; MARTINS, 2019, p. 41).
} 
moment of the movement of construction of the Brazilian nation" (SANTOS; SILVA, 2017, p. 445, author's translation $)^{54}$.

Thus, Freyre is associated with the ideology of racial democracy ${ }^{55}$ (MARTINS; BARROS, 2019), "which corresponds to the perception of the non-preponderance of race in social relations in Brazil, the absence of prejudice and thus the conformation of a harmonious pattern in the relationships developed between blacks and whites" (p. 41, author's translation $)^{56}$.

Unesco, interested in the thesis that there was no racial discrimination in Brazil because of Freyre's appointments, decided to promote a study in the 1950s to prove these claims. It was discovered, however, due to investigations led by Florestan Fernandes ${ }^{57}$ (SCHWARCZ, 2019), that "the greatest legacy of the slave system, in force here for more than three centuries, would not be a mestiçagem unifying the nation, but rather the consolidation of a deep and entrenched social inequality" (p. 17-18, author's translation) ${ }^{58}$. This sociologist identified that the Brazilian would have a kind of reactive prejudice, that is, the prejudice against prejudice (FERNANDES, apud SCHWARCZ, 2019), preferring to deny rather than recognize and change this reality, denouncing the tale of the three races (SCHWARCZ, 2019) as a "myth of racial democracy" (p. 18).

"Studies have revealed the perpetuation of a pattern unfavorable to blacks, who remained, even after so long extinction of slavery, occupying the worst positions in our social structure" (MARTINS; BARROS, 2019, p. 43, author's translation) $)^{59}$, and his work "The integration of black people into class society", written in 1965, shows a society marked by

\footnotetext{
54 “descreve como exitoso o processo de formação nacional apoiado não numa base racial homogênea, mas orgânica e unitária, e pode ser lido como momento fundamental do movimento de construção da nação brasileira" (SANTOS; SILVA, 2017, p. 445).

${ }^{55}$ Almeida (2018), relying on Schwarcz (2014), states that in the 1930s, the notion of scientific racism was changed to the ideology of racial democracy.

56 “que corresponde à percepção da não preponderância da raça nas relações sociais do Brasil, a inexistência do preconceito e, assim, a conformação de um padrão harmônico nas relações desenvolvidas entre negros e brancos" (MARTINS; BARROS, 2019, p. 41).

${ }^{57}$ For Ribeiro and Faustino (2017, p. 168), "the themeization of black (men) as a problem is also reproduced in the spaces they seek to advocate in their defense", referring to the book "A integração do Negro na Sociedade de Classes" (Black Integration in Class Society, author's translation), written in 1964, by Florestan Fernandes, criticizing the work. Author's translation. Original: "a tematização dos (homens) negros como um problema se reproduz também nos espaços que procuram advogar em sua defesa” (RIBEIRO; FAUSTINO, 2017, p. 168). Bento (2002) also makes explicit his criticisms of Fernandes' appoitments.

58 “o maior legado do sistema escravocrata, aqui vigente por mais de três séculos, não seria uma mestiçagem a unificar a nação, mas antes a consolidação de uma profunda e entranhada desigualdade social" (SCHWARCZ, 2019, p. 17-18).

59 “os estudos relevaram a perpetuação de um padrão desfavorável aos negros, que permaneciam, mesmo depois de tanto tempo extinta a escravidão, ocupando as piores colocações em nossa estrutura social" (MARTINS; BARROS, 2019, p. 43). The authors refer to Telles (2003).
} 
inequality (BENTO, 2002). Black activism contributed immensely to this discussion, because "from the end of the 1970s, showed the perversion of this type of official discourse, which had the potential to dodge the strength of social movements that fought for real equality and inclusion" (SCHWARCZ, 2019, p. 18, author's translation) ${ }^{60}$.

Santos e Silva (2017) report that Fernandes' research allowed studies in the field of sociology, as Carlos Hasenbalg' research. He criticizes the Paulista Sociological School, especially Florestan Fernandes, because of the relationship between racism and "residues" of a slave society, and indicates that "racial discrimination in Brazil is a direct result of inequalities between whites and 'non-wites' in different spheres [...] and was built over time by the capitalist order" (HASENBALG, apud SANTOS; SILVA, 2017, p. 449, author's translation) ${ }^{61}$. According to Santos e Silva (2017, p. 449, author's translation), the author Hasenbalg (2005):

\begin{abstract}
States that black people, historically, have been exploited economically and that this exploitation has taken place practically through classes or fractions of white dominant classes. Reinforces that the opening of the social structure towards mobility is directly linked to the color of the skin, and, in this context, race constitutes a selective criterion in access to education and work ${ }^{62}$.
\end{abstract}

For Silva (2018), it is important to understand the myth of racial democracy, "because it is from it that racism has been historically denied as a 'structuring' element of social relations in Brazil" (p. 26, author's translation) ${ }^{63}$. Schwarcz (2019, p. 18, author's translation) states that "naturalizing inequality, evading the past, is characteristic of authoritarian governments [...]. But it is also the formula applied, with relative success, among us, brazilians" ${ }^{\prime 64}$.

So the importance of memory, which usually differs from history. While this has a load of clashes, disagreements and disputes, proving to be inconclusive (SCHWARCZ, 2019), memory brings "to the center of analysis a subjective dimension when translating the past into

\footnotetext{
60 “a partir do fím da década de 1970, mostrou a perversão desse tipo de discurso oficial, o qual tinha a potencialidade de driblar a força dos movimentos sociais que lutavam por real igualdade e inclusão" (SCHWARCZ, 2019, p. 18).

61 “a discriminação racial no Brasil é resultado direto das desigualdades entre brancos e 'não brancos' em diferentes esferas [...] e foi construída ao longo do tempo pela ordem capitalista” (HASENBALG; APUD SANTOS; SILVA, 2017, p. 449).

62 "Afirma que os negros, historicamente, foram explorados economicamente e que essa exploração se deu praticamente por meio de classes ou frações de classes dominantes brancas. Reforça que a abertura da estrutura social em direção à mobilidade está diretamente ligada à cor da pele, e, nesse âmbito, a raça constitui um critério seletivo no acesso à educação e ao trabalho" (SANTOS; SILVA, 2017, p. 449).

63 “pois é a partir dele que o racismo tem sido historicamente negado como elemento 'estruturante' das relações sociais no Brasil" (SILVA, 2018, p. 26).

64 “naturalizar a desigualdade, evadir-se do passado, é característico de governos autoritários [...]. Mas é também a fórmula aplicada, com relativo sucesso, entre nós, brasileiros” (SCHWARCZ, 2019, p. 18).
} 
the first person and devote to him a certain memory: that which produces it. Thus, it recovers the 'present of the past' and makes the past become [...] present" (p. 19-20, author's translation $)^{65}$. The official history is successful in the invention of facts (BERTÚLIO, 1989). "Many and many stories were taught to us, convenient with the Brazilian ruling class, thus contributing to the educational system and education, with the consolidation of the dominant ideology of that elite" (BERTÚLIO, 1989, p. XLVI, our translation) ${ }^{66}$.

Thus, the relevance of the study of racial issues is noted, given that the construction of a history is not done in a naive way, but part of a strategy of the State, which enhances certain events and softens others, which are still reflected today. This situation ends up authorizing a single interpretation, obliterating others (SCHWARCZ, 2019).

It is common for black people to be seen as a social problem. The idea remains that the inequality that affects them would result from structural problems in the country, or because of slavery, with no relation to prejudice (SANTOS; SILVA, 2017). "Identity narratives [...] since the 1930s [...] orientates the national modus vivendi guided by the denial of racism as a structuring phenomenon of social relations" (SILVA, 2018, p. 10, our translation) ${ }^{67}$. "Are there racial inequalities? There are! Is there a black deficienty? There is! Does it have anything to do with white? No, it is because the black people was a slave, *that is, it is the inert legacy of a past in which whites seem to have been absent" (BENTO, 2002, p. 3, author's translation) ${ }^{68}$. It is possible to conclude that there is a need to question the problems of reality, in order to recognize prejudice, discrimination and racism:

They say asking is a way to resist. I think that a critical history is one that knows
how to "denaturalize" what seems to be given by biology and that therefore
presents itself as immutable. There is nothing in our blood or in the DNA of
brazilians that indicates that all these elements are immune to our human and
citizen action. Nor is it a good idea to do the opposite: relegate to the past and to
the "other", who lived before us, everything that bothers us in the present. Racist
is "someone else" (not myself), [...] inequality was a consequence of slavery, and
period. What is certain is that it is impossible to play in a distant and unattainable

65 "para o centro da análise uma dimensão subjetiva ao traduzir o passado na primeira pessoa e a ele devotar uma determinada lembrança: daquele que a produz. Assim, ela recupera o 'presente do passado' e faz com que o passado vire [...] presente" (SCHWARCZ, 2019, p. 19-20).

66 "Muitas e muitas estórias nos foram ensinadas, convenientes com a classe dirigente brasileira, contribuindo, desta forma, o sistema de ensino e educação, com a consolidação da ideologia dominante daquela elite" (BERTÚLIO, 1989, p. XLVI).

67 "Narrativas identitárias [...] desde os anos 1930 [...] orientam o modus vivendi nacional norteado pela negação do racismo como fenômeno estruturante das relações sociais" (SILVA, 2018, p. 10).

68 "Há desigualdades raciais? Há! Há uma carência negra? Há! Isso tem alguma coisa a ver com o branco? Não! É porque o negro foi escravo, *ou seja, é legado inerte de um passado no qual os brancos parecem ter estado ausentes" (BENTO, 2002, p. 3). 
time all our current ills. [...] Therefore, to those who do not understand why we live, nowadays, such an intolerant and violent period; to those who receive with surprise so many authoritarian manifestations or the disclosure, without hesitation, of speeches that openly undo a catalogue of civil rights that seemed consolidated; to those who watch from the stands the addition of a politics of hatred and that turns opponents into enemies, I invite you to a journey towards our history, our past and our present (SCHWARCZ, 2019, p. 24-25, author's emphasis and translation $)^{69}$.

Considering that - and especially of Schwarcz's (2019) notes - it is possible to see the need for the recognition of racism, which is an important step in the fight against the discriminatory reality. This allows to concretize - and see the importance - of actions to face it.

Returning to Freud's category of denial, which consists in the "process by which the individual, although formulating one of his desires, thoughts or feelings, so far 'recalcado', continues to defend himself against it, denying what belongs to it" (LAPLANCE; PONTALIS, 1970; APUD GONZALEZ, 1988, p. 69, author's translation and emphasis) ${ }^{70}$, Gonzalez (1988) points that racism "in a brazilian way" acts by denying "latinoamefricanidade". In Brazil, racism has an impact on black people, and in parallel there is the denial of the existence of this social posture, as when someone believe in racial democracy. According to the author, in "societies of Latin origin, we have racism in disguise or [...] racism by denial. Here the 'theories' of miscegenation, assimilation and 'racial democracy' prevail" (p. 72, author's translation) ${ }^{71}$. She clarifies that Latin America is an excellent example of where racism by denial occurs ${ }^{72}$.

\footnotetext{
69 “Dizem que perguntar é uma forma de resistir. Pois penso que uma história crítica é aquela que sabe “desnaturalizar" o que parece dado pela biologia e que se apresenta, por consequência, como imutável. Não existe nada em nosso sangue ou no DNA dos brasileiros que indique serem todos esses elementos imunes à nossa ação humana e cidadã. Também não é boa ideia fazer o oposto: relegar ao passado e ao "outro", que viveu antes de nós, tudo que nos incomoda no presente. Racista é "alguém outro" (não eu mesmo), [...] a desigualdade foi consequência da escravidão, e ponto-final. O certo é que é impossível jogar num tempo distante e inatingível todas as nossas mazelas atuais. [...] Portanto, a quem não entende por que vivemos, nos dias de hoje, um período tão intolerante e violento; a quem recebe com surpresa tantas manifestações autoritárias ou a divulgação, sem peias, de discursos que desfazem abertamente de um catálogo de direitos civis que parecia consolidado; a quem assiste da arquibancada ao acrescimento de uma política de ódios e que transforma adversários em inimigos, convido para uma viagem rumo à nossa história, nosso passado e nosso presente" (SCHWARCZ, 2019, p. 24-25, grifo das autoras).

70 "processo pelo qual o indivíduo, embora formulando um de seus desejos, pensamentos ou sentimentos, até aí recalcado, continua a defender-se dele, negando o que lhe pertença” (LAPLANCE; PONTALIS, 1970; apud GONZALEZ, 1988, p. 69).

71 "sociedades de origem latina, temos o racismo disfarçado ou [...] racismo por denegação. Aqui prevalecem as 'teorias' da miscigenação, da assimilação e da 'democracia racial'”' (GONZALEZ, 1988, p. 72).

72 At the end of her appoitments, the author adds the relevance of studying the construction of Iberian countries, referring to Gonzalez, 1988b (GONZALEZ, 1988). For her, Latin American racism, marked by whitening, distributes blacks and Indians in a situation of subordination, in classes that suffer exploitation. Whitening disseminates the idea that the values and classifications made by whites in the West are the correct ones, based on Gonzalez (1988a) (GONZALEZ, 1988a).
} 
In other words, there is a recalque in the social posture, to the extent that people act in a racist manner, while deny this action, through beliefs in a racial democracy or the nonexistence of racism. The scenario does not contribute to the recognition of this reality, and consequently leads to a lack of effective confrontation actions.

Ribeiro (2019) encourages individuals to think about what actions they have taken as anti-racists - a fight that should be fought by all. The recognition of oppression and the struggle to bring it to an end are necessary. The lack of reflection contributes to the persistence of discrimination, which is why it is essential to discuss blackness, whiteness, lack of occupation of spaces by a portion of individuals - denaturalizing this inequality - and to think about transformative actions. Perception is a path to change, as it allows for reflection on privileges, as well as bringing responsibility for injustices that fall on a piece of the population (RIBEIRO, 2019).

It is necessary to transcend the understanding of one's own privileges, and antiracist actions are indispensable. The author defends responsibility precisely for generating actions (RIBEIRO, 2019). From Ribeiro (2019), it is possible to conclude that the recognition of racism is related to the perception not only of privileges, but also of the structural approach that should fall on this reality, which demands responsability, and consequently, antirracist actions that generate social transformations. In other words: recognition generates responsibility, which influences antirracist attitudes.

Several authors point, in this context, strategies: Almeida (2018) argues that effective anti-racist actions are necessary to face the problem, and exemplifies, through institutional postures, how this could happen: values equality and diversity internally and externally; allowing the ascendence of minorities to have better positions; possibility of debates and if necessary, reformulation of actions of the institution itself, and intermediation of issues involving race and gender.

Furthermore, for Silva (2018), the recognition of racism allows the creation of educational strategies that are not limited to the school environment, and that encourage the "construction of new identity narratives that circumvent the 'myth' and enhance new forms of subjectivity, because denying racism in Brazilian society [...] works as the statement of 'confession'" (p. 27, author's translation) ${ }^{73}$.

73 “construção de novas narrativas identitárias que contornem o 'mito' e potencializem novas formas de subjetividade, pois negar o racismo na sociedade brasileira [...] funciona como o enunciado da "confissão"” (SILVA, 2018, p. 27). 
Santos (2018) argues that affirmative actions are important, and highlights that the Black Movement, in anti-racist struggle, is generally responsible for these actions ${ }^{74}$. In addition, based on Jaccoud and Beghin, Santos (2018) identifies five categories of policies to address racial inequalities, as follows: "Repressive Policies; Valuation Policies; Policies to Combat Direct Inequalities; Policies to Expand Interlocution/Political Representativeness Spaces; and Policies to Combat Institutional Racism" (p. 2125, author's translation) ${ }^{75}$.

Santana and Pereira (2018, p. 1560, author's translation) states that "to combat disguised racism, it is not enough to refute individual conduct, proactive measures are needed on the part of institutions and society in order to combat the harmful institutional and cultural racism"76, citing the example of affirmative cultural policies, which would be directed only for black people, indigenous or other groups that have suffered state and social neglect, allowing them to connect to cultural goods ${ }^{77}$.

In Azevedo (2019), the relationship between racial quotas and affirmative actions is observed $^{78}$. For the author, those "are a concrete expression of the strength of the tension of the class struggle and the power of the resistance of the black people" (p. 133, author's translation $)^{79}$. The public university is an institution that has possibility to enable social change. The post-graduate course is also an important focus on the antiracist struggle, in order to avoid being just another place where inequalities and privileges occur (AZEVEDO, 2019).

\footnotetext{
${ }^{74}$ In this sense, he adds that affirmative actions are "a new form of action of the Black Movement, and a new relationship between it and the State and Brazilian society, in which the movement places on the public agenda the need for public policies, questioning the ideology [...] of racial democracy" (SANTOS, 2018, p. 2125). Author's translation. In original: "uma nova forma de ação do Movimento Negro, e uma nova relação deste com o Estado e com a sociedade brasileira, na qual o movimento insere na agenda pública a necessidade de políticas públicas, questionando a ideologia [...] da democracia racial" (SANTOS, 2018, p. 2125). For Almeida (2018, p. 26-27), referring to Gomes (1995), "Affirmative action policies - which establish discriminatory treatment in order to correct or compensate inequality - are examples of positive discrimination". Author's translation. In original: "Polícias de ação afirmativa - que estabelecem tratamento discriminatório a fim de corrigir ou compensar a desigualdade - são exemplos de discriminação positiva".

75 "Políticas Repressivas; Políticas de Valorização; Políticas de Combate Direto a Desigualdades; Políticas de Ampliação de espaços de Interlocução/Representatividade Política; e Políticas de Combate ao Racismo Institucional" (SANTOS, 2018, p. 2125).

76 "para combater o racismo disfarçado, não basta rebater as condutas individuais, são necessárias medidas proativas por parte das instituições e da sociedade, a fim de se combater o nefasto racismo institucional e cultural" (SANTANA; PEREIRA, 2018, p. 1560).

${ }^{77}$ Also in this sense, the authors then mention Vich (2014).

${ }^{78}$ Affirmative actions related to race, in addition to black people's rights, were attacked, remaining under the surveillance of certain racist and conservative sectors in Brazil. Racial quotas have already been questioned about constitutionality in the Federal Supreme Court (AZEVEDO, 2019).

79 "são uma expressão concreta da força do tensionamento da luta de classes e do poder da resistência do povo negro" (AZEVEDO, 2019, p. 133).
} 
That's because post-graduate studies form masters and doctors. It forms the specialists who, in the bulge of capitalist society, structured by class inequality and structural racism, will potentially occupy the best positions in the labor market, the best political positions, will earn the best salaries, will occupy the best social positions in terms of status and financial conditions, and will occupy positions of power. The postgraduate system trains the future teachers who will occupy the faculty chairs in higher education [...]. It trains the future teachers, managers, [...] rectors of public units. And it is these people who will make political decisions, who will occupy the spaces of power in society, who will have access to high standard consumer goods, [...]. But, above all, it is these people who will dispute the best social positions in a society that is structured by class inequality (AZEVEDO, 2019, p. 192, author's translation) ${ }^{80}$.

However, inequality still persists: according to the author, research was conducted on the pos-graduate programs of the Federal University of Espírito Santo (UFES), according to the Research and Post-Graduate Studies Sector (PRPPG) (2019), in order to analyze whether there was inequality in the admission to pos-graduate programs between white and black people. Part of the results were sent by PRPPG to the researcher, showing that between the years 2016 and 2018 only $1 \%$ of PhD students and $8 \%$ of Master's students were black. Only $9 \%$ of $\mathrm{PhD}$ students were pardos, while in the master's degree they were $26 \%$. On the other hand, whites entered predominantly: in the master's degree, $40 \%$ were white, and in the doctorate, $16 \%$ (AZEVEDO, 2019).

If structural racism is the reason why blacks have greater difficulties in obtaining a quality education for Ribeiro (2019), it is possible to conclude that access to education is an action to confront structural racism, contributing to the formation of more black authors. According to Azevedo (2019, p. 240, author's translation), "racial quotas need to go beyond the guarantees of quantitative entry of black students into university. Today, the antiracist struggle must defend, above all, the public, free, quality and universalist university" ${ }^{81}$. Ribeiro (2019) encourages the reading of black authors, emphasizing the existence of epistemicide ${ }^{82}$, which

\footnotetext{
80 "Isso porque a pós-graduação forma mestres e doutores. Forma os especialistas que, no bojo da sociedade capitalista, estruturada pela desigualdade de classes e pelo racismo estrutural, potencialmente ocuparão os melhores postos no mercado de trabalho, as melhores posições políticas, ganharão os melhores salários, ocuparão as melhores posições sociais em termos de status e condições financeiras, e que ocuparão posições de poder. A pós-graduação forma os futuros docentes que ocuparão as cadeiras do magistério no ensino superior [...]. Forma os futuros professores, gestores, [...] reitoras das unidades públicas. E são essas pessoas que tomarão decisões políticas, que ocuparão os espaços de poder na sociedade, que terão acesso a bens de consumo de alto padrão, [...]. Mas, sobretudo, são essas pessoas que disputarão as melhores posições sociais em uma sociedade que é estruturada pela desigualdade de classes" (AZEVEDO, 2019, p. 192).

81 "as cotas raciais precisam ir além das garantias do ingresso quantitativo de alunos negros na universidade. Hoje, a luta antirracista precisa defender, acima de tudo, a universidade pública, gratuita, de qualidade e universalista" (AZEVEDO, 2019, p. 240).

82 The author points that Sueli Carneiro, in her doctoral thesis, translated the expression epistemicide, which originally came from Boaventura Sousa Santos. Gonzalez (1988), addressing "amefricanidade", adds that due to various researchers on the subject, it is possible to verify that violence and racism were responsible for damaging
} 
refers to the erasure of knowledge coming from oppressed groups. She cites as an example the fact that it is common, in different courses, that bibliographies produced by black people or women are not indicated. Thus, the access to education contributes to have more black authors producing knowledge (RIBEIRO, 2019).

From what was exposed, racial discrimination in Brazil has a historical past, marked by colonization, pseudo-scientific theories that sought to hierarchize individuals, as well as a long period of slavery. However, people should not only blame the past for the existence of racism: it is important to recognize the current contributions to the permanence of this system. Institutional violence, lack of government interest, whiteness symptoms ${ }^{83}$, are situations that contribute to the perpetuation of racism, which must be recognized in order to be faced. In this sense, the next item discusses examples of ways in which recurring discriminations present themselves today.

\section{WHAT "REMAINS" OF RACISM IN BRAZIL ${ }^{84}$}

The racist posture has institutional reflexes, giving rise to manifestations of the State itself, such as police violence, having as a suspect element subjectively determined individuals ${ }^{85}$, in addition to being reflected in violence practiced against black people by the rest of society.

Almeida (2018) points out different conceptions of racism, which occur in the individualistic, institutional and structural form, and this research focuses on the last form of interpretation. From this author's, it is possible to conclude that racism is rooted in society, not limited to institutions, being "a result of the very social structure, that is, the 'normal' way in

\footnotetext{
the historical legacy, in addition to the dignity of these individuals, their history, contributions in various areas such as science, philosophy and religion, among others.

${ }^{83}$ Expression based on Bento (2002).

${ }^{84}$ The expression "what remains" was inspired by the title of the work "What remains of the dictatorship: the Brazilian exception", by Edson Teles and Vladimir Safatle, 2010. The original title is "O que resta da ditadura: a exceção brasileira" (Author's translation).

85 According to the study "Suspicious Element": police approach and discrimination in the city of Rio de Janeiro, by Silvia Ramos and Leonarda Musumeci, from 2004, and "Racial filtration: the color in the selection of the suspect", by Geová da Silva Barros, produced in 2008. Original titles: "Elemento suspeito": abordagem policial e discriminação na cidade do Rio de Janeiro; "Filtragem racial: a cor na seleção do suspeito". (Our translation).
} 
which political, economic, legal and even family relations are constituted, not being a social pathology or an institutional disorder"86 (ALMEIDA, 2018, p. 38, author's translation) ${ }^{87}$.

[...] If it is possible to speak of institutional racism, it means that, in some way, the imposition of racist rules and standards by the institution is somehow linked to the social order that it seeks to protect. Just as the institution has its performance conditioned to a previously existing social structure - with all the conflicts that are its own -, the racism that this institution expresses is also part of this same structure. Institutions are only the materialization of a social structure or a mode of socialization that has racism as one of its organic components. To put it more directly: institutions are racist because society is racist (ALMEIDA, 2018, p. 36, author's emphasis, our translation $)^{88}$.

Zulu Araujo, former president of the Palmares Foundation, states that the first decade of the 21st century was positive for the black movement, highlighting several achievements, such as Law $n^{\circ} 10.639$ of $2003^{89}$, which introduced the discipline of African History and AfroBrazilian Culture in schools, black ministers, racial quotas in higher education, among other advances. However, there was a freeze in the political agenda of the black movement, associated with internal problems, loss of land for lack of claims, and recalled the existence of certain threats, such as the media with racist campaigns, growth of religious intolerance, high rates of murders of blacks, among other similar situations (ARAUJO, 2017).

Perhaps we can conclude that a good way to better understand whiteness and the process of whitening is to understand the projection of white on the black, born of fear, surrounded by silence, faithful guardian of privileges. What we see committed in this process is the very capacity of identification with our neighbor, thus creating the basis for a generalized intolerance against everything that can represent the difference (BENTO, 2002, p. 14, our translation) ${ }^{90}$.

\footnotetext{
86 Then, the author alludes to "Racism is structural", referring to Bonilla-Silva (2006) (ALMEIDA, 2019).

87 "uma decorrência da própria estrutura social, ou seja, do modo "normal" com que se constituem as relações políticas, econômicas, jurídicas e até familiares, não sendo uma patologia social e nem um desarranjo institucional" (ALMEIDA, 2018, p. 38). (Author's translation).

88 “....] Se é possível falar de um racismo institucional, significa que, de algum modo, a imposição de regras e padrões racistas por parte da instituição é de alguma maneira vinculada à ordem social que ela visa resguardar. Assim como a instituição tem sua atuação condicionada a uma estrutura social previamente existente - com todos os conflitos que lhe são próprios -, o racismo que esta instituição venha a expressar é também parte desta mesma estrutura. As instituições são apenas a materialização de uma estrutura social ou de um modo de socialização que tem o racismo como um de seus componentes orgânicos. Dito de modo mais direto: as instituições são racistas porque a sociedade é racista” (ALMEIDA, 2018, p. 36, grifo do autor).

${ }^{89}$ Silva (2018) points that this law, along with the National Curriculum Guidelines for Education in Ethnic-Racial Relations and for the Teaching of Afro-Brazilian and African History and Culture of 2004, are achievements of anti-racist movements in Brazil. The Guideline starts from the premise that the existence of racism in Brazil must be recognized in order for anti-racist policies to be effective. Thus, the overcoming of the myth of racial democracy, seen as a blockade to anti-racist education, is highlighted.

90 "Talvez possamos concluir que uma boa maneira de se compreender melhor a branquitude e o processo de branqueamento é entender a projeção do branco sobre o negro, nascida do medo, cercada do silêncio, fiel guardião dos privilégios. O que se vê comprometido nesse processo é a própria capacidade de identificação com o próximo,
} 
Considering the existence of a pattern that has been, over the centuries, disseminated as the correct, honest, beautiful, which must be followed, excluding those who did not fit in there, it is possible to understand, without major surprise, that what remains of racism in Brazil is: structural discrimination, institutional, religious intolerance, prejudice against musicality, culture, among other similar manifestations.

Thus, in Brazil there are (re)veiled ${ }^{91}$ forms of racism, both in an institutional form and directly practiced against black people by the rest of the population. Examples are: a) alarming data on violence against black people. According to the Atlas of Violence 2019, organized by the Institute of Applied Economic Research and the Brazilian Forum of Public Security, the violance indicates an enormous racial inequality in the country, being necessary public security policies, besides the guarantee of other rights, that consider the diversities to be well directed to their target audience (IPEA; BRAZILIAN FORUM OF PUBLIC SECURITY, 2019). It was found that in 2017, of the total number of homicides committed, $75.5 \%$ occurred against black people. For every 100,000 black people, 43.1 are killed, while this proportion for people who are not black makes up 16.0 deaths (IPEA; BRAZILIAN PUBLIC SECURITY FORUM, 2019).

The 2016 Violence Map, which deals with firearm homicides in Brazil, shows that between 2003 and 2014, in the country as a whole, there was a fall of $27.1 \%$ in homicides against white people. When the victims are black, the rates increased by $9.9 \%$ for the same period (WAISELFISZ, 2016). In 2003 black victimization in Brazil was 71.7\%. At the same time, in 2014 this number was $158.9 \%$. The data vary according to the States of the Federation, so that only local studies could explain the variations of these indexes, bringing information that went beyond the inheritance of slavery or institutional racism (WAISELFISZ, 2016).

Considering also the hidden cipher about the real dimension of violence against black people in Brazil, it is possible to see how alarming these data are, showing a lack of action to face the problem through specific actions not only of the State, but also of the part of the society responsible for the victimizations.

Regarding item b) of this discussion, institutional manifestations are pointed out: For Collins (2015, p. 20), racism can be located in institutions, so that "addressing racism implies

criando-se, desse modo, as bases de uma intolerância generalizada contra tudo o que possa representar a diferença" (BENTO, 2002, p. 14).

${ }^{91}$ Santos $(2014$, p. 279) states that there is a "veiled and implicit" racism in Brazil. His words originally are "velado e implícito" (SANTOS, 2014, p. 279, author's translation). 
recognizing the ways in which it is institutionalized and its manifestations in less evident situations" (SILVA, 2018, p. 26, author's translation) ${ }^{92}$.

In the legal field, "the study of law in Western capitalist societies gives rise to the realization that racism and all aggressions and violations [...] coexist with the purest and most rigid criteria of just law, legal equality, principles of humanity [...], etc" (BERTÚLIO, 1989, p. XVIII, author's translation) ${ }^{93}$. "It occurs, therefore, perfect symbiosis between the State, the Law and society as to the legal instance, in order to camouflage the racial differences and legitimize [...]" (BERTÚLIO, 1989, p. XIX, author's translation) ${ }^{94}$. It is on the "'sacred' cloak of law" discriminated and discriminators, black and white, affirming to the discriminated the "naturalness" and "justice" related to discrimination and inferiority (BERTÚLIO, 1989, p. XIX).

An example of this scenario is the discussion on the ownership of quilombos remnants ${ }^{95}$. Article 68 of the Transitory Constitutional Provisions Act (ADCT) of Brazil's 1988 Federal Constitution provided that these groups would be entitled to the lands they occupy, which is why definitive ownership should be recognized through the issue of titles by the State. Despite this, the constitutional provision was not complied with, and the demarcation of the lands in the appropriate manner was not carried out (VIEIRA; QUINTANS; CARLET, 2017). Torres (2020, p. 197) questions the reason why "around five thousand remaining quilombo's communities, of which around three thousand are recognized and there are almost two thousand lawsuits filed at INCRA ${ }^{96}$, only one hundred and eighty one have their territories duly titled?"97.

\footnotetext{
92 "abordar o racismo implica em reconhecer as formas pelas quais ele se institucionaliza e suas manifestações nas situações menos evidentes” (SILVA, 2018, p. 26).

93 "o estudo do Direito nas sociedades ocidentais capitalistas, enseja a constatação de que o racismo e todas as agressões e violações [...] coexistem com os mais puros e rígidos critérios de direito justo, igualdade jurídica, princípios de humanidade [...], etc" (BERTÚLIO, 1989, p. XVIII).

94 "Ocorre, pois, perfeita simbiose entre o Estado, o Direito e a sociedade quanto à instância jurídica, no sentido de camuflar as diferenças raciais e legitimar [...]” (BERTÚLIO, 1989, p. XIX).

95 "They are ethnic groups predominantly made up of the black population, rural or urban, who define themselves from the relations with their territories as spaces of survival, identity and spiritual and cultural reproduction" (VIEIRA; QUINTANS; CARLET, 2017, p. 557). Author's translation. In original: "São grupos étnicos predominantemente constituídos pela população negra, rural ou urbana, que se autodefinem a partir das relações com seus territórios como espaços de sobrevivência, de identidade e de reprodução espiritual e cultural" (VIEIRA; QUINTANS; CARLET, 2017, p. 557). The quilombos didn't end up with the abolition of slavery, conserving themselves through the remnants. The period of slavery was a time of struggle and resistance, and one of the forms of resistance were the quilombos existing in Brazil, which currently has several communities considered remnants (TORRES, 2020).

${ }^{96}$ National Institute of Settlement and Agrarian Reform (TORRES, 2020, não paginado). Author's translation. In original: Instituto Nacional de Colonização e Reforma Agrária (TORRES, 2020, não paginado).

${ }^{97}$ Author's translation. In original: "cerca de cinco mil comunidades remanescentes de quilombos, das quais cerca de três mil são reconhecidas e existindo quase dois mil processos instaurados no INCRA, apenas cento e oitenta e uma têm seus territórios devidamente titulados?" (TORRES, 2020, p. 197).
} 
In response, the author considers that this article "was approved at the centennial celebrations of the formal abolition of slavery, and most of the constituents probably did not imagine it could have any effect" (TORRES, 2020, p. 198) ${ }^{98}$. The following facts corroborate his thesis: the article does not appear in the main text of the Constitution, but in the ADCT; it was only regulated by decree fifteen years after the enactment of the Constitution, in addition to having suffered several actions of unconstitutionality ${ }^{99}$; the constant racist character of the reality of Brazil, which demonstrates ethnic and institutional racism ${ }^{100}$ (TORRES, 2020). These are factors that make the recognition of territories difficult, as well as "the rise of the black population to public positions, education, the university and public policies that enable this access, following the example of quotas" (p. 198) ${ }^{101}$.

Addressing Decree $\mathrm{n}^{\circ} 4.887$ of $2003^{102}$ - "which regulates the procedure for identification, recognition, delimitation, demarcation and titling of land occupied by remnants of quilombola's communities" (BRASIL, 2003, author's translation) ${ }^{103}$, Vieira, Quintans and

\footnotetext{
${ }_{98}$ Author's translation. In original: "foi aprovado no bojo dos festejos do centenário da abolição formal da escravatura e, muito provavelmente, a maioria dos constituintes não imaginava que ele pudesse produzir algum efeito" (TORRES, 2020, p. 198).

${ }^{99}$ These actions demonstrate the farce of a supposed "racial democracy" and equality among Brazilian individuals (TORRES, 2020).

${ }^{100}$ According to the author, "this institutional racism is aggravated by a legal issue regarding the unity of the national territory, which would not include the existence of other territories with relative autonomy, a customary right that privileges the collective, its own traditions and cultures, as happens in relation to traditional peoples and communities, and quilombolas in particular. If this institutional behavior does not become so evident, it manifests itself in the actions and omissions, in the long and slow processes of recognition" (TORRES, 2020, p. 198). Author's translation. In original: "esse racismo institucional é agravado por uma questão jurídica no que diz respeito à unidade do território nacional, que não comportaria a existência de outros territórios com relativa autonomia, um direito costumeiro que privilegia o coletivo, tradições e culturas próprias, como acontece em relação aos povos e comunidades tradicionais, e quilombolas, em particular. Se esse comportamento institucional não fica tão evidente, ele se manifesta nas ações e omissões, na delonga e morosidade dos processos de reconhecimento" (TORRES, 2020, p. 198).

101 Author's translation. In original: "a ascensão da população negra aos cargos públicos, à educação, à universidade e às políticas públicas que possibilitem esse acesso, a exemplo das cotas" (TORRES, 2020, p. 198). 102 Vieira, Quintans and Carlet (2017, p. 7) point that this decree adopted the self-definition criterion, following the Convention 169 from OIT, related to indigenous and tribal people. Thus, in Article 2, it was defined as remaining of the quilombo communities "the ethnic-racial groups, according to criteria of self-attribution, with their own historical trajectory, endowed with specific territorial relations, with presumption of black ancestry related to resistance to the historical oppression suffered". Quintans and Lopes (2014), based on Figueiredo (2009), note that anthropologists define these communities on the basis of a "re-emerged" concept (in original, "ressemantizado", that is, the groups are understood on the basis of an extensive interpretation, as opposed to the "dicionarized" concept, which "interprets the constitutional article in a restricted manner and understands the quilombos only as spaces of 'escaped blacks"'. Author's translation. In original: "interpreta o artigo constitucional de forma restrita e entende os quilombos unicamente como espaços de "negros fugidos"” (QUINTANS; LOPES, 2014, não paginado). The facts in discution were considered only a matter of law, which is why it does not require openness to other areas of knowledge than the legal. Considering that, the authors question what is considered the source of law (VIEIRA; QUINTANS; CARLET, 2017).

103 "que regulamenta o procedimento para identificação, reconhecimento, delimitação, demarcação e titulação das terras ocupadas por remanescentes das comunidades dos quilombos” (BRASIL, 2003).
} 
Carlet (2017) point to the fact that it was the object of Direct Unconstitutionality Action $\mathrm{n}^{\circ}$ $3.239 / 2004$, and a public hearing was requested, which was refused by the minister relator. The denial was criticized by the authors, because the impediment of vast social participation in the judicial sphere is a reflection of the very formation of this field, considering it is attached to a specific conception of law, in addition to having a historical structuring in which it remains "alien to the desires of social movements for access to law and justice"104 (author's translation) (p. 576). For the authors, the analysis of this action, in addition to other constant cases pending in the Judiciary related to the struggle for territories of these communities, allows to understand obstacles imposed by the judicial system itself on black communities, making access to citizenship and ownership of territories difficult ${ }^{105}$.

It is important to recognize the territory of the remaining quilombos, since that it is in those places where, "besides the production and reproduction of life, exercises territoriality in the sense of 'understanding what belongs to it', the relationship with nature, religious practices, the maintenance of traditions and respect for ancestry" (TORRES, 2020, p. 199, author's translation $)^{106}$. In other words, the granting of this right is a condition for preserving the culture of these communities. For Quintans, Vieira and Carlet (2017, p. 585, author's translation), "denying the right to land means denying the very cultural, historical, social existence of quilombola identity"107.

104 "alheio aos desejos dos movimentos sociais por acesso ao direito e à justiça" (VIEIRA; QUINTANS; CARLET, 2017, p. 565).

${ }^{105}$ Based on Quintans and Hagino (2015), they point out that sometimes the Judiciary guarantees rights, sometimes denies them. In addition, the authors noted that there is disagreement on the interpretation of Article 68 of the ADCT, regarding its extension. Analyzing a specific case, a kind of fracture was observed within the judiciary in situations where it is necessary to assume an opinion. This fracture "is the result of the countless social pressures that have tensioned judges and outsiders, to overcome apartheid espitêmico (sic) and to effect territorial rights. It is in contexts like these that it becomes possible to resign categories that transcend colonial notions - such as the classic character of private property associated with land use as a source of economic exploitation and associated with concepts that persist in considering 'quilombola remnants' as descendants of 'black fugitives' - in order to open paths that may lead to the necessary decolonization of law" (VIEIRA; QUINTANS; CARLET, 2017, p. 584). Author's translation. In original: "é resultado das inúmeras pressões sociais que têm tensionado juízes/as e desembargadore/as, a ultrapassar o apartheid espitêmico (sic) e efetivar direitos territoriais. É em contextos como esses, que se torna possível ressignificar categorias que transcendem noções coloniais - como o caráter clássico da propriedade privada associada ao uso da terra como fonte de exploração econômica e associada a conceitos que persistem em considerar os 'remanescentes de quilombos' como descendentes de 'negros fugitivos' - para abrir caminhos que possam levar à necessária descolonização do direito" (VIEIRA; QUINTANS; CARLET, 2017, p. 584). Moreover, according to the authors, within the institutions, the Executive, Legislative and Judiciary powers generate obstacles to ensure rights. Outside the institutions, there are several actions filed by landowners who try to annul the titles of the territories of these communities (VIEIRA; QUINTANS; CARLET, 2017).

106 "além da produção e reprodução da vida, se exerce a territorialidade no sentido de "perceber aquilo que lhe pertence', a relação com a natureza, as práticas religiosas, a manutenção das tradições e respeito à ancestralidade" (TORRES, 2020, p. 199).

107 "negar o direito à terra significa negar a própria existência cultural, histórica, social da identidade quilombola". (QUINTANS; VIEIRA; CARLET, 2017, p. 585). 
Both the State and the Law reproduce racism, including through its political and civil superstructure (BERTÚLIO, 1989), "in order to generalize and develop the concepts and stereotypes formed throughout the life of black people in this country" (p. XXI, our translation $)^{108}$.

Duarte, Avelar and Garcia (2018) studied narratives present in focus groups conducted with black people and military police officers. As for the police officers, the objective was to understand the criteria for them to approach an individual considered "suspicious". On the other hand, the intention of the young black people was to verify what it was like to live "under suspicion". After defining certain conclusions about the narratives, they point that "if, on the one hand, police practices denounce how strong the identification between criminality and blackness is, on the other hand, we have to consider that these practices, as put, are not the exclusive responsibility of the police" (p. 3332, our translation) ${ }^{109}$, so that the social, institutional and judicial spheres allow disrespect. Thus, in order to achieve a positive change in police procedures, it is necessary to change other instances, especially the Judiciary (DUARTE; AVELAR; GARCIA, 2018).

Munanga (2003) highlights that in Brazil there is a form of implicit racism, except for police violence, which is not subtle. Ferreira (2019), on the other hand, problematizing police violence in Brazil with lethal results, understands them as violations of fundamental rights, framing as situations that prevent the realization of the rule of law.

To illustrate, twelve military shot a car ${ }^{110}$, in 2019, in the city of Rio de Janeiro: two hundred and fifty-seven shots were fired, causing the death of two people and injuring a third, in addition to putting at risk another part of the people present in the vehicle. The military was also charged with failure to provide assistance. It is said that the reason for the attack was the

\footnotetext{
108 "de forma a generalizar e desenvolver os conceitos e estereótipos formados ao longo da vida do negro neste país” (BERTÚLIO, 1989, p. XXI).

109 "se de um lado, as práticas policiais denunciam como é demasiadamente forte a identificação feita entre criminalidade e negritude, de outro, temos que considerar que estas práticas, como postas, não são de responsabilidade exclusiva dos policiais" (DUARTE; AVELAR; GARCIA, 2018, p. 3332).

${ }^{110}$ Referring to this murder, for Ribeiro (2019), the issue of violence only gains space in public discussions when an extreme situation is widely publicized. She considers that this violence is part of a public security policy that generates repression and exterminates black individuals, especially men. It is common for the judiciary to act as if it were an "extension of the police car", because it does not demand an investigation or deny the contradictory, that is, the possibility of defense by individuals inserted in the system based on the criterion of selectivity. It is interesting to say that "war agains drugs" in practice generates a war against black people. Law 11.343/2006 (Drug Law) differentiates the trafficker from the user based on subjective criteria, often leading to racial discrimination. The author cites as an example a black man who was condemned for the crime of trafficking on the basis of 0.02 grams of marijuana.
} 
"confusion" of that car with another, which was stolen (JUCÁ, 2019a) ${ }^{111}$. In an earlier report on this case, it was stated that the military acted in response to an "unjust assault" by "assailants" who initiated the shooting, concluding that in reality the shooting occurred by "mistake" (JUCÁ, 2019b) .

It is also worth pointing out the statement of judge of law, in 2019, that "the defendant does not have the standard stereotype of a bandit, has skin, eyes and light hair, not being subject to be easily confused" (FREIRE, 2019, author's translation) ${ }^{112}$.

In 2020, a fourteen-year-old teenager was killed while playing in his backyard - during the pandemic caused by the coronavirus - in an operation carried out by the Federal Police with the Coordination of Special Resources in Rio de Janeiro, Complexo do Salgueiro. A Civil Police helicopter took the victim, and the family remained without news until the following day, when they identified the body at the Medico-Legal Institute (MIRANDA, 2020).

It is also necessary to talk about, among other violences agains black people, the murder of Marielle Franco: former councilwoman, black, single mother, lesbian and considered "daughter of the community of Maré"113 - thus noting the correlation with race, gender and region - was linked to human rights discutions and criticism of police actions in poor communities. A resolution of the investigation has not yet been obtained. However, this murder is associated with a political crime. The news has gained national and international repercussions (SCHWARCZ, 2019, p. 180), "leading the activist to circumvent the anonymity that usually covers up cases of people who have the same colour, gender and social origin as her but have not obtained such political visibility" (SCHWARCZ, 2019, p. 181, author's translation $)^{114}$.

On the other hand, the part c) refers to discriminations regarding the musicality associated with black people, who are consequently stigmatized, as can be seen from the study of Trotta (2016). The author highlighted conflicts related to funk, which "can be thought of as a synthesis of several social nuisances that are often condensed and processed by the musical experience" (TROTTA, 2016, p. 87, our translation) ${ }^{115}$.

\footnotetext{
${ }^{111}$ Even if this were the case, it would be disproportional (JUCÁ, 2019).

112 “o réu não possui o estereótipo padrão de bandido, possui pele, olhos e cabelos claros, não estando sujeito a ser facilmente confundido" (FREIRE, 2019).

113 This is the "largest slum complex" in the state of Rio de Janeiro (SCHWARCZ, 2019, p. 180).

114 "levando a ativista a driblar o anonimato que costuma encobrir casos de pessoas que têm a mesma cor, gênero e origem social que ela mas não obtiveram tal visibilidade política" (SCHWARCZ, 2019, p. 181).

115 "pode ser pensado como uma síntese de diversos incômodos sociais que são muitas vezes condensados e processados pela experiência musical” (TROTTA, 2016, p. 87).
} 
"The link between funk and the young, peripheral and popular universe is undoubtedly one of the fundamental elements of its discomfort. Funk is the 'other' talking, singing, dancing and having fun" (TROTTA, 2016, p. 94, our translation) ${ }^{116}$. There is repression into this musical gender: Pacification Police Units were installed in 2008 in Rio de Janeiro slums, and one of the first orientations was related to the prohibition of funk at partys, its public execution or its presence at the door of residences (BURGOS ET TAL, 2012; APUD TROTTA, 2016).

As d) there is the cultural discrimination linked to religiosity, another example of repression of cultural manifestations related to black people. Leandro and Sanfilippo (2018) highghts that at the beginning of 2017, several terreiros de candomblé were attacked in Brazil, and that "the self-styled traffickers of Christ [...] invaded, plundered terreiros and attacked priests and priestesses in their traditional communities with African roots" (p. 89).

According to Russo e Almeida (2016, p. 469, author's translation), "the discussion on cases of discrimination and prejudice against practitioners of African religions is part of a much broader debate on structural racism in Brazilian society" ${ }^{117}$. Considering the attacks, historical issues, religious racism and the rise of neo-Pentecostal churches, there is a narrative that demonises African religions, i.e., there is a political-institutional power that contributes to this scenario (LEANDRO; SANFILIPPO, 2018).

\begin{abstract}
Neo-Pentecostal religious racism reflects a problem of all brazilian society: the complete ignorance of African, Afro-Brazilian, indigenous and Afro-Amerdian history. Misinformation and prejudice, generated a culture of hatred fed back by racism. If we observe how education is processed on the "school floor", we will ask ourselves: what have we learned? How do we learn? What are the predominant peoples, ethnicities and cultural matrixes in the curricula? The little we know about Afro-Brazilian, African, indigenous and Afro-American history and culture is told from the point of view of the colonizer, it is eurocentric (LEANDRO; SANFILIPPO, 2018, p. 92, our translation) ${ }^{118}$.
\end{abstract}

\footnotetext{
116 "A vinculação do funk com o universo jovem, periférico e popular é, sem dúvida, um dos elementos fundamentais de seu incômodo. O funk é o ‘outro' falando, cantando, dançando e se divertindo" (TROTTA, 2016, p. 94).

117 “a discussão sobre os casos de discriminação e preconceito contra os praticantes das religiões de matriz africana faz parte de um debate muito mais amplo sobre o racismo estrutural existente na sociedade brasileira" (RUSSO; ALMEIDA, 2016, p. 469).

118 "O racismo religioso neopentecostal, reflete um problema de toda a sociedade brasileira: o completo desconhecimento da história africana, afro-brasileira, indígena e afro-ameríndia. Desinformações e preconceitos, geraram uma cultura de ódio retroalimentada pelo racismo. Se observarmos como se processa a educação no "chão da escola", nos questionaremos: o que aprendemos? Como aprendemos? Quais são os povos, etnias e matrizes culturais predominantes nos currículos? O pouco que conhecemos da história e da cultura afro-brasileira, africana, indígena e afro-ameríndia, são contadas sob o ponto de vista do colonizador, são eurocêntricos" (LEANDRO; SANFILIPPO, 2018, p. 92).
} 
Neopentecostal churches have not only financial and media power, but also politicalelectoral power, which manifests itself in the so-called "evangelical benches"119. As this power grows, conservative positions also increase, contrary to the rights already achieved (LEANDRO; SANFILIPPO, 2018).

Considering the conservative and authoritarian political context of Brazil, a report by Folha de São Paulo, highlights that in that state, during the 2018 elections, a peak of crimes related to intolerance was reached. In the months of August, September and October, when the campaign developed, there were, on average, sixteen cases per day, totaling more than three times what was happening in the first semester. The report had as its source Newsletters of Occurrence related to various intolerances, such as homophobia, transphobia, racism, either by ethnicity, color, origin, religion, among others. In the months of the campaign, crimes related to religious intolerance grew $171 \%$ compared to the previous three months, and those of race or color prejudice increased 15\% (ESTARQUE; FARIA, 2019).

It is interesting to bring, in this context, the criticism that Daou (2019) makes of the expression "religious tolerance". If everyone has religious freedom, "the relationship should be one of equality of religious exercise, of respect. Tolerance presupposes a tolerant and another tolerated, but in a State where all are equal, the question is: who are the tolerant and who are the tolerated?" (p. 173, author's translation) ${ }^{120}$. Concludes that in practice, are "tolerants [...] the members of religions that have not ceased to be hegemonic with the passage to the liberal state, while those who are tolerated are those who still suffer prejudice and do not feel free to openly manifest their religious beliefs" (p. 173, author's translation) ${ }^{121}$.

This situation finally denotes that racism must be faced, leaving behind the myth of a racial democracy. As pointed out, there is no harmony and respect on the part of the State towards black people in Brazil, and there is a difficulty on the part of most individuals to recognize structural racism, which influences that attitudes are not taken to avoid new violations of rights.

\footnotetext{
119 Original: "bancada evangélica" (LEANDRO; SANFILIPPO, 2018, p. 95, our translation).

120 “a relação deveria ser de igualdade de exercício religioso, de respeito. Tolerância pressupõe um tolerante e um outro tolerado, porém, em um Estado em que todos são iguais, questiona-se: quem são os tolerantes e quem são os tolerados?" (DAOU, 2019, p. 173).

121 "tolerantes [...] os membros das religiões que não deixaram de ser hegemônicas com a passagem para o Estado liberal, já os tolerados são aqueles que ainda sofrem preconceitos e não se sentem livres para manifestar abertamente suas crenças religiosas" (DAOU, 2019, p. 173). After, the autor mentions that there are fires on "terreiros", according to Valdevino (2014), and atheists do not usually express their position, according to Bonilla (2013), and questions: "is the tolerance of classical liberalism enough for us? (DAOU, 2019, p. 173). Author's translation. In original: “a tolerância do liberalismo clássico nos basta?” (DAOU, 2019, p. 173).
} 


\section{CONCLUSION}

Considering that the right to racial non-discrimination is not effective in Brazil, the research started from the following problem: how is it possible to face racism in this country? The hypothesis, which was confirmed during the bibliographical review, was that the confrontation can be carried out from the recognition of this structural reality.

In this sense, the lessons of Schwarcz (2019), Ribeiro (2019) and Gonzalez (1988) were indispensable. From the authors, the questioning of reality is emphasized, denaturing inequalities; the importance of memory, which differs from history, highlighting that the production of knowledge by the black population was sometimes erased, generating an epistemicide, according to Ribeiro (2019); the presence of a recalque in the difficulty of recognising oneself as a racist, to the extent that although individuals have racist actions, they do not identify themselves like that; the need for the recognition of racism as a structural reality, so that this posture generates responsibility, and consequently antirracist actions that can transform reality.

An example of anti-racist actions are the affirmatives ones, such as racial quotas. Considering Azevedo (2019) and Ribeiro (2019) in particular, it is essential that blacks be able to access spaces that were denied for them, such as education. Therefore, they should be present not only in undergraduate but also in pos-graduate studies, becoming professionals such as teachers, rectors and others who may occupy spaces of power. Despite the existence of quotas, there is still inequality in the entry of blacks and nonblacks in the academic space, as demonstrated by Azevedo (2019) based on research provided by the Research and PostGraduate Studies sector (PRPPG) of the Federal University of Espírito Santo.

In the discussion about still existing inequalities, several cases of (re)veiled racism in Brazil were demonstraded. These are police actions against determined groups, using violence, sometimes lethal; disrespect for culture and religiosity also through violence; discussions about the constitutionality of regulating the land of remaining quilombos, places necessary for cultural preservation - as can be seen from Torres (2020), Quintans, Vieira and Carlet (2017) - among others.

Anti-racist actions are required for social transformations to be achieved, and to the extent that they should be practiced by all, as Ribeiro (2019) argues, it is essential that, initially, individuals recognize the racism present in their realities so that they can manage actions that 
contribute to change. Effective equality among individuals is sought, so that they are not chosen in a filtered and subjective way in police approaches, do not have negative stereotypes or have disrespected their voices, cultures and religious manifestations.

\section{REFERENCES}

ALMEIDA, Silvio Luiz de. O que é racismo estrutural? Belo Horizonte: Letramento, 2018.

ARAÚJO, Wagner Santos. Os estereótipos e a violência enquanto linguagem: diálogos e reflexões. In: DIAS, Ana Rosa Ferreira; MENEGALDO, Karina (Org.). Anais VI Jornada DiME, São Paulo, v. 1. São Paulo: Puc-Sp. 2014, não paginado. Disponível em: https://anaisdodime.wordpress.com/. Acesso em: 15 jun. 2020.

ARAUJO, Zulu. Avanços e retrocessos na luta dos Negros na Atualidade. Revista Raça, [s. 1.], 15 mar. 2017. Disponível em: https://revistaraca.com.br/avancos-e-retrocessos-na-lutados-negros-na-atualidade/. Acesso em: 15 jun. 2020.

AZEVEDO, Simone Lima. Quando pretos pintam na UFES, a universidade se pinta de preto? Reflexões sobre racismos e antirracismos institucionalizados. Dissertação (Mestrado em Polícia Social do Centro de Ciências Jurídicas e Econômicas) - Universidade Federal do Espírito Santo, Vitória, 2019. Disponível em: http://200.137.65.30/handle/10/11380. Acesso em: 15 jun. 2020.

BARROS, Bárbara Sepúlveda; MARTINS, Luci Helena. "Existir, resistir, exigir! Aspectos da construção histórico-ideológica do racismo brasileiro e o lugar do movimento negro na luta a favor da sua desconstrução". Revista Prâksis, Rio Grande do Sul, v. 1, n. 1, p. 32-49, jan-abr. 2019. ISSN: 2448-1939. Disponível em:

https://periodicos.feevale.br/seer/index.php/revistapraksis/article/view/1732. Acesso em: 15 jun. 2020. Doi: https://doi.org/10.25112/rpr.v1i0.1732.

BARROS, Geová da Silva. "Filtragem racial: a cor na seleção do suspeito". Revista Brasileira de Segurança Pública 3, [s. 1.], v. 2, n. 1, p. 134-155. 2008. Disponível em:

http://revista.forumseguranca.org.br/index.php/rbsp/article/view/31. Acesso em: 15 jun. 2019.

BATISTA, Vera Malaguti. Introdução crítica à criminologia brasileira. 2 ed. Rio de Janeiro: Revan, 2018.

BENTO, Maria Aparecida Silva. Branqueamento e branquitude no Brasil. In: CARONE, Iray; APARECIDA, Maria (Org.). Psicologia social do racismo - estudos sobre branquitude e branqueamento no Brasil. Petrópolis, RJ: Vozes, 2002, p. 25-58. Disponível em: http://www.media.ceert.org.br/portal-3/pdf/publicacoes/branqueamento-e-branquitude-nobrasil.pdf. Acesso em: 15 jun. 2020. 
BERTÚLIO, Dora Lucia de Lima. Direito e relações raciais: uma introdução crítica ao racismo. 229 f. Dissertação (Mestrado Ciências Humanas - Especialidade Direito) - Curso de Pós-Graduação em Direito, Universidade Federal de Santa Catarina, Florianópolis, 1989.

BRASIL. Constituição (1988). Brasília, DF: Senado, 1988. Disponível em: http://www.planalto.gov.br/ccivil_03/constituicao/constituicao.htm. Acesso em: 15 jun. 2020.

BRASIL. Lei $n^{\circ}$ 7.716, de 5 de janeiro de 1989. Define os crimes resultantes de preconceito de raça ou de cor. Brasília, DF: Congresso Nacional, 1989. Disponível em: http://www.planalto.gov.br/ccivil_03/leis/17716.htm. Acesso em: 15 jun. 2020.

BRASIL. Decreto $n^{\circ} 4.887$, de 20 de novembro de 2003. Regulamenta o procedimento para identificação, reconhecimento, delimitação e titulação das terras ocupadas por remanescentes das comunidades dos quilombos de que trata o art. 68 do Ato das Disposições Constitucionais Transitórias. Brasília, DF: Congresso Nacional, 2003. Disponível em: http://www.planalto.gov.br/ccivil_03/decreto/2003/D4887.htm\#: :text=DECRETO\%20N\%C 2\%BA\%204.887\%2C\%20DE\%2020,Ato\%20das\%20Disposi\%C3\%A7\%C3\%B5es\%20Const itucionais\%20Transit\%C3\%B3rias.. Acesso em: 15 jun. 2020.

CARVALHO, José Murillo de. Cidadania no Brasil: o longo caminho. 10 ed. Rio de Janeiro: Civilização Brasileira, 2008.

COLLINS, Patricia Hills. Em direção a uma nova visão: raça, classe e gênero como categorias de análise e conexão. In: MORENO, Renata (Org.). Reflexões e práticas de transformação feminista (Coleção Cadernos Sempreviva. Série Economia e Feminismo, 4). São Paulo: SOF, 2015. p. 13-43. Disponível em: http://www.sof.org.br/wpcontent/uploads/2016/01/reflex\%C3\%B5esepraticasdetransforma\%C3\%A7\%C3\%A3ofeminis ta.pdf. Acesso em: 15 jun. 2020.

COMPARATO, Fábio Konder. A afirmação histórica dos direitos humanos. 7 ed. São Paulo: Editora Saraiva, 2010.

DAOU, Saada Zouhair. "Os tolerantes e os tolerados: as limitações do conceito de tolerância religiosa". Revista Eletrônica Direito e Sociedade, Canoas, v. 7, n. 2, p. 167-180, ago. 2019. ISSN: 23188081. Disponível em: https://revistas.unilasalle.edu.br/index.php/redes/article/view/3818. Acesso em: 15 jun. 2020. DOI: http://dx.doi.org/10.18316/redes.v7i2.3818.

DAVIS, Angela. Mulheres, raça e classe. Tradução: Heci Regina Candiani. São Paulo: Boitempo, 2016.

DUARTE, Evandro Piza; AVELAR, Laís da Silva; GARCIA, Rafael de Deus. "Suspeitos? Narrativas e expectativas de jovens negros e negras e policiais militares sobre a abordagem policial e a discriminação racial em Brasília, Salvador e Curitiba”. Quaestio Iuris, Rio de Janeiro, v. 11, n. 4, p. 3316-3336. 2018. Disponível em: https://www.epublicacoes.uerj.br/index.php/quaestioiuris/article/view/34319. Acesso em: 15 jun. 2020. Doi: https://doi.org/10.12957/rqi.2018.34319. 
ESTARQUE, Marina; FARIA, Flávia. Registros de intolerância triplicaram em SP na última campanha eleitoral. Folha de S. Paulo, 13 jan. 2019. Disponível em:

https://www1.folha.uol.com.br/cotidiano/2019/01/registros-de-intolerancia-triplicaram-em-spna-ultima-campanha-eleitoral.shtml. Acesso em: 15 jun. 2020.

FERREIRA, Poliana da Silva. "Direitos fundamentais e letalidade policial: sentidos opostos numa mesma trilha". Revista Eletrônica Direito e Sociedade, Canoas, v. 7, n. 2, p. 111-126, ago. 2019. ISSN: 23188081. Disponível em:

https://revistas.unilasalle.edu.br/index.php/redes/article/view/4656. Acesso em: 15 jun. 2020. Doi: http://dx.doi.org/10.18316/redes.v7i2.4656.

FREIRE, Simone. Juíza diz que acusado "não possui estereótipo de bandido" por ter "pele, olhos e cabelos claros". AlmaPreta.com, [s. 1.], 7 mar. 2019. Disponível em:

https://www.almapreta.com/editorias/realidade/juiza-diz-que-acusado-nao-possui-estereotipode-bandido-por-ter-pele-olhos-e-cabelos-claros. Acesso em: 15 jun. 2020.

GONZALEZ, Lélia. A categoria político-cultural de amefricanidade. In: Tempo Brasileiro. Rio de Janeiro, n. 92/93, jan./jun., p. 69-82, 1988.

HUNT, Lynn. A invenção dos direitos humanos: uma história. Tradução: Rosaura Eichenberg. São Paulo: Companhia das Letras, 2009.

INSTITUTO DE PESQUISA ECONOMICA APLICADA; FÓRUM BRASILEIRO DE SEGURANÇA PÚBLICA (Org.). Atlas da Violência 2019. Brasília: Rio de Janeiro: São Paulo. 2019. Disponível em:

http://www.ipea.gov.br/portal/index.php?option=com_content\&view=article\&id=34784\&Ite mid=432. Acesso em: 15 jun. 2020.

JUCÁ, Beatriz. Doze militares são denunciados por fuzilamento de músico e catador no Rio. El País. São Paulo, 10 mai. 2019. Disponível em: https://brasil.elpais.com/brasil/2019/05/11/politica/1557530968_201479.html. Acesso em: 15 jun. 2020.

JUCÁ, Beatriz. 80 tiros e o risco da impunidade no Rio de Janeiro. El País. São Paulo, 9 abr. 2019b. Disponível em:

https://brasil.elpais.com/brasil/2019/04/08/politica/1554759819_257480.html. Acesso em: 15 jun. 2020.

LEANDRO, Marcos Eduardo; SANFILIPPO, Lúcio Bernard. "Deus e o diabo no mercado: reflexões e narrativas de um racismo religioso vigente". Revista Periferia, Rio de Janeiro, v. 10, n. 1, p. 89-99, jan-jun. 2018. ISSN: 1984-9540. Disponível em: https://www.epublicacoes.uerj.br/index.php/periferia/article/view/31449. Acesso em: 15 jun. 2020. Doi: https://doi.org/10.12957/periferia.2018.31449.

LIMA, Francielle Elisabet Nogueira. Perspectivas críticas sobre a tutela jurídica de pessoas trans: diálogos entre estudos (trans)feministas e direito. Dissertação (Mestrado) - Programa de Pós-Graduação em Direito da Universidade Federal do Paraná, Curitiba, 2018. 
MIRANDA, Eduardo. Adolescente desaparecido em ação policial é encontrado morto no Rio de Janeiro. Brasil de Fato, Rio de Janeiro, 19 mai. 2020. Disponível em:

https://www.brasildefato.com.br/2020/05/19/adolescente-desaparecido-em-acao-policial-eencontrado-morto-no-rio-de-janeiro. Acesso em: 15 jun. 2020.

MOREIRA, Adilson José. Cidadania sexual: estratégia para ações inclusivas. Revisão: Fabiana Carvalho. Belo Horizonte: Arraes Editores, 2017.

MUNANGA, Kabengele. Uma abordagem conceitual das noções de raça, racismo, identidade e etnia. Palestra proferida no $3^{\circ}$ Seminário Nacional Relações Raciais e Educação - PENESB, RJ, 05/11/2003. Disponível em: https://www.geledes.org.br/wpcontent/uploads/2014/04/Uma-abordagem-conceitual-das-nocoes-de-raca-racismo-dentidadee-etnia.pdf. Acesso em: 15 jun. 2020.

RAMOS, Silvia; MUSUMECI, Leonarda. “'Elemento suspeito””. Abordagem policial e discriminação na cidade do Rio de Janeiro. Boletim Segurança e Cidadania”, [s. 1.], n. 8, p. 116, nov. 2004. Disponível em: https://www.ucamcesec.com.br/boletim/elemento-suspeitoabordagem-policial-e-discriminacao-na-cidade-do-rio-de-janeiro/. Acesso em: 15 jun. 2020.

RIBEIRO, Alan Augusto Moraes; FAUSTINO, Deivison Mendes. Negro tema, negro vida, negro drama: estudos sobre masculinidades negras na diáspora. Transversos: Revista de História. Rio de Janeiro, n. 10, p. 163-182, ago. 2017. Disponível em: https://www.epublicacoes.uerj.br/index.php/transversos/article/view/29392. Acesso em: 15 jun. 2020. Doi: https://doi.org/10.12957/transversos.2017.29392.

RIBEIRO, Djamila. O que é: lugar de fala? Belo Horizonte (MG): Letramento: Justificando, 2017.

RIBEIRO, Djamila. Pequeno manual antirracista. São Paulo: Editora Schwarcz, 2019.

RUSSO, Kelly; ALMEIDA, Alessandra. "Yalorixás e educação: discutindo o ensino religioso nas escolas". Cadernos de Pesquisa, São Paulo, v. 46, n. 160, p. 466-483, abr-jun. 2016.

ISSN: 0100-1574. Disponível em: http://www.scielo.br/scielo.php?pid=S010015742016000200466\&script=sci_abstract\&tlng=pt. Acesso em: 15 jun. 2020. Doi: http://dx.doi.org/10.1590/198053143305.

SANTANA, Ana Claudia Farranha; PEREIRA, Paulo Fernando Soares. "As instituições do sistema de justiça brasileiras e os ciclos das políticas públicas: possibilidades na defesa das ações afirmativas e combate ao racismo institucional e cultural". Quaestio Iuris, Rio de Janeiro, v. 11, n. 3, p. 1542-1574. 2018. ISSN: 1516-0351. Disponível em: https://www.epublicacoes.uerj.br/index.php/quaestioiuris/article/view/30842. Acesso em: 15 jun. 2020. Doi: 10.12957/rqi.2018.30842.

SANTOS, Raquel Amorim dos; SILVA, Rosângela Maria de Nazaré Barbosa e. "Racismo científico no Brasil pós-escravatura". Revista Contemporânea de Educação, Rio de Janeiro, v. 12, n. 25, p. 438-454, set-dez. 2017. ISSN: 1809-5747. Disponível em:

https://revistas.ufrj.br/index.php/rce/article/view/11956. Acesso em: 15 jun. 2020. Doi: https://doi.org/10.20500/rce.v12i25.11956. 
SANTOS, Renato Emerson dos. "Ações afirmativas no combate ao racismo: uma análise da recente experiência brasileira de promoção de políticas públicas". Quaestio Iuris, Rio de Janeiro, v. 11, n. 3, p. 2101-2128. 2018. ISSN: 1516-0351. Disponível em: https://www.epublicacoes.uerj.br/index.php/quaestioiuris/article/view/30413. Acesso em: 15 jun. 2020.

SANTOS, Ronaldo Adriano dos. Ações afirmativas para negros no ensino superior através das políticas de cotas. Revista Jurídica Cesumar, Maringá, v. 14, n. 1, p. 265-284, jan-jun. 2014. ISSN: 1677-64402. Disponível em:

http://periodicos.unicesumar.edu.br/index.php/revjuridica/article/view/3284. Acesso em: 15 jun. 2020.

SCHWARCZ, Lilia Moritz. Sobre o autoritarismo brasileiro. Revisão: Angela das Neves; Huendel Viana. São Paulo: Companhia das Letras, 2019.

SILVA, Mozart Linhares da. "Democracia racial e dispositivos de segurança no Brasil: contribuições para uma educação antirracista”. Revista Educação e Cultura Contemporânea, [S. I,], v. 15, n. 38, p. 7-31. 2018. ISSN: 2238-1279. Disponível em:

http://periodicos.estacio.br/index.php/reeduc/article/viewArticle/2533. Acesso em: 15 jun. 2020. Doi: DOI10.5935/2238-1279.20180002PDF.

TELES, Edson; SAFATLE, Vladimir (Org.). O que resta da ditadura: a exceção brasileira. São Paulo: Boitempo, 2010.

TORRES, Paulo Rosa. Comunidades remanescentes de quilombos: da escravatura à disputa contemporânea por seus territórios tradicionais. Tese (Planejamento Territorial e Desenvolvimento Social) - Universidade Católica do Salvador, Salvador, 2020. Disponível em: http://ri.ucsal.br:8080/jspui/handle/prefix/1536. Acesso em: 14 jun. 2020.

TROTTA, Felipe da Costa. "O funk no Brasil contemporâneo: uma música que incomoda". Latin American Research Review, [s. 1.], v. 51, n. 4, p. 86-101. 2016. ISSN: 1542-4278.

VIEIRA, Fernanda; QUINTANS, Mariana Trotta Dallalana; CARLET, Flávia. Sob o rufar dos ng'oma: o judiciário em disputa pelos quilombolas. Rev. Direito e Práx., Rio de Janeiro, v. 8, n. 1, p. 556-591. 2017. ISSN: 2179-8966. Disponível em: https://www.epublicacoes.uerj.br/index.php/revistaceaju/article/view/27770. Acesso em: 15 jun. 2020.

QUINTANS, Mariana trotta Dallalana; LOPES, Aline Caldeira. Participação social nas ações de constitucionalidade sobre as políticas de ação afirmativa para negros no Brasil. In: XXIII Encontro Nacional Conpedi/UFSC, 2014, Florianópolos/SC. MAILLART, A. S.; TAVARES NETO, J. Q.; BARBOSA, C. M. (Coord.). Acesso à Justiça II. Florianópolis: CONPEDI, 2014. p. 403-425. Disponível em:

http://publicadireito.com.br/publicacao/ufsc/livro.php?gt=173. Acesso em: 15 jun. 2020.

WAISELFISZ, Julio Jacobo. Mapa da Violência 2016: Homicídios por armas de fogo no Brasil. Assistente: Silvia Andrade Magnata da Fonte. Coordenação Web: Juliana Pisaneschi. Revisora: Margareth Doher. Brasília, DF: Flacso Brasil. 2016. Disponível em: http://flacso.org.br/?attachment_id=16684. Acesso em: 15 jun. 2020. 
Quaestio Iuris

Trabalho recebido em 18 de novembro de 2019

Aceito em 04 de dezembro de 2020 